\title{
An Intensive Cultural Resources Investigation for the Redbud Pump Station Transmission Water Line Project Collin County, Texas
}

Karen Belvin

Follow this and additional works at: https://scholarworks.sfasu.edu/ita

Part of the American Material Culture Commons, Archaeological Anthropology Commons, Environmental Studies Commons, Other American Studies Commons, Other Arts and Humanities Commons, Other History of Art, Architecture, and Archaeology Commons, and the United States History Commons

Tell us how this article helped you.

This Article is brought to you for free and open access by the Center for Regional Heritage Research at SFA ScholarWorks. It has been accepted for inclusion in Index of Texas Archaeology: Open Access Gray Literature from the Lone Star State by an authorized editor of SFA ScholarWorks. For more information, please contact cdsscholarworks@sfasu.edu. 


\section{An Intensive Cultural Resources Investigation for the Redbud Pump Station Transmission Water Line Project Collin County, Texas}

\section{Creative Commons License}

\section{(c) (1) \&}

This work is licensed under a Creative Commons Attribution-NonCommercial 4.0 International License 


\section{AN INTENSIVE CULTURAL ReSOURCES INVESTIGATION FOR THE Redbud Pump Station Transmission Water line Project Collin COUNTY, TeXas}

Prepared for:

CitY OF MCKInNEY

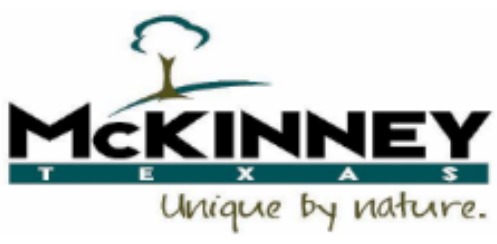

Prepared by:

BGE, Inc.

2595 Dallas Parkway

Suite 101

Frisco, Texas 75034

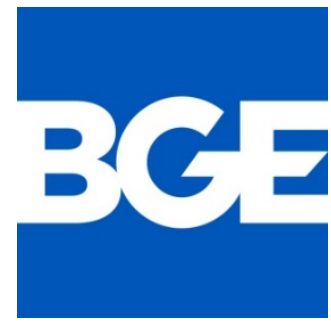

January 7, 2020 


\title{
An Intensive Cultural Resources InVESTIGATION for the Redbud Pump Station Transmission Water Line Project Coluin COUNTY, TEXAS
}

\author{
Prepared for: \\ City of McKinney \\ 222 N. Tennessee Street \\ McKinney, Texas 75069 \\ City Project No.: WA-4340 \\ Prepared by: \\ BGE, Inc. \\ 2595 Dallas Parkway \\ Suite 101 \\ Frisco, Texas 75034 \\ Principal Investigator: \\ J. Philip Washington, R.P.A. \\ Antiquities Permit: 8763 \\ Report Author: \\ Karen Belvin, M.A., R.P.A \\ Contributions by: \\ Ernesto Maycotte, MBA, RPA \\ Lauren Miller \\ Lindsay Vermillion \\ Jonathan Welch, MA, RPA
}

January 7,2020 


\section{Table of Contents}

Management Summary

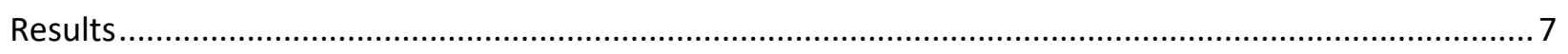

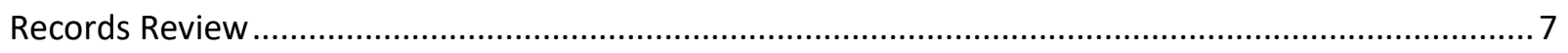

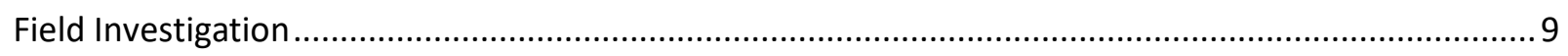

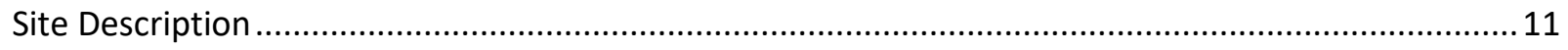

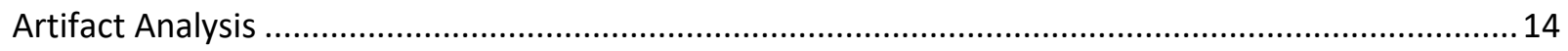

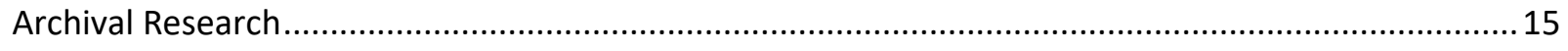

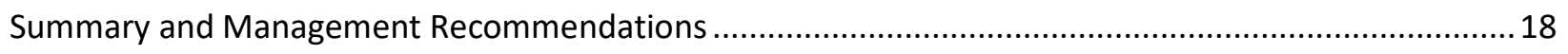

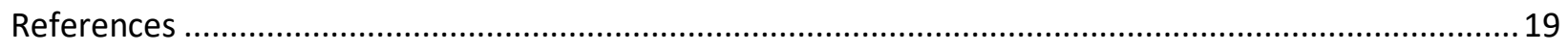

Appendix A: Project Maps

Appendix B: Project Photographs 


\section{List of Tables}

Table 1: Cultural Resources Investigations within 805 m (0.5 mi) Study Area

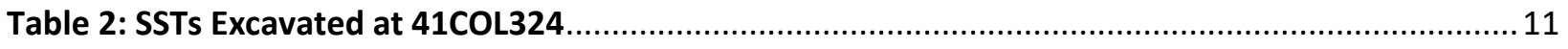

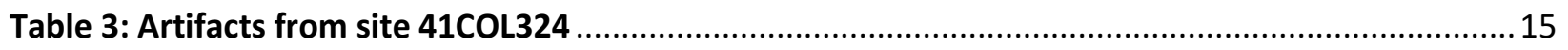

Table 4: Owners of Property where Site 41COL324 is Located ..................................................... 15 


\title{
Management Summary
}

\author{
Project: $\quad$ Redbud Pump Station Transmission Water Line Project
}

Project Sponsor: $\quad$ City of McKinney

City Project No.: $\quad$ WA-4340

Project Description: The City of McKinney is proposing to construct 2.2 kilometers ( $\mathrm{km}$; 1.4 miles [mi]) of new 42-inch (in) water transmission line within a permanently maintained utility easement that ranges in width from 8 to 19 meters (m; 26 to 62 feet [ft]), in west-central Collin County, Texas. Improvements to the existing transmission network will enhance water conveyance operations and reduce maintenance costs for the City of McKinney.

Project Location: The project is situated in the northwestern extent of the City of McKinney. The area where the project is located is depicted on the 2016 McKinney West, Texas-Collin County USGS 7.5-Minute Topographic Quadrangle map at an average elevation of $642 \mathrm{ft}$ above mean sea level. The project area is bounded by Bloomdale Road to the north, Justice Street to the south, Redbud Boulevard to the east, and an existing 30-in water transmission line northeast of South Hardin Boulevard, between County Road 164 and Bloomdale Road.

Project APE:

The area of potential effect (APE) for this project encompasses 5.4 hectares (ha; 13.3 acres [ac]) inclusive of the transmission line permanent easement and temporary workspaces to accommodate excavators, equipment, personnel, bore pits, and tie-in connections for installation. Depth below ground surface is expected not to exceed $8 \mathrm{~m}(27 \mathrm{ft})$.

Dates of Field Effort: February 6-8, April 10, and November 17, 2019

Field Investigation: The City of McKinney contracted BGE, Inc. to conduct an intensive pedestrian survey augmented by shovel testing for the project. Under the supervision of Principal Investigator, Karen Belvin, the survey was led by Crew Chief, Lindsay Vermillion, with Ciara Bamsch-Robinson serving as supporting crew member. The field effort required 46 person-hours to complete. Current Principal Investigator for the project is J. Philip Washington.

Number of Sites: $\quad$ One new historic site (41COL324) was identified as a result of this field effort. Site 41COL324 appears to represent a historic-period refuse midden related to a late nineteenth or early twentieth century farmstead or other domestic occupation. It consists of a shallow subsurface deposit of historic artifacts, all excavated from one shovel test, as well as two discrete areas of sparse surface scatters of historic artifacts. Two wells are also located within the site. No standing structures remain. Archival research on the owners failed to associate the property with a person or family of historical significance. 
Recommendations: BGE archeologists conclude that portions of 41COL324 within the proposed project lack potential for future study and does not meet any criteria for evaluation that would make it potentially eligible for listing on the NRHP. Therefore, BGE recommends that portions of 41COL324 within the proposed project be determined as Ineligible for inclusion in the NRHP, and the project be allowed to proceed without further consultation in the vicinity of 41COL324. Furthermore, because the two wells are located

BGE recommends that the City avoids impacts to those two wells during construction activities, by placing high visibility construction fencing around them to avoid heavy equipment inadvertently tracking through the area and damaging the wells. 


\section{Definition of the Project}

\section{Introduction}

The City of McKinney (City) is proposing to construct and maintain 2.2 kilometers ( $\mathrm{km}$; 1.4 miles [mi]) of 42inch (in) water transmission line for the Redbud Pump Station Transmission Water Line Project (Project) located within the City of McKinney, in west-central Collin County, Texas (Appendix A, Figure 1). On behalf of the City, BGE, Inc. (BGE) conducted an intensive pedestrian survey augmented by shovel testing of the Project. Because the proposed project is being contracted by the City of McKinney, a political subdivision of the state of Texas, the project sponsor is required under the Texas Antiquities Code and the Texas Natural Resources Code Chapter 26 'Rules of Practice and Procedure for the Antiquities Code of Texas' to obtain a Texas Antiquities Permit to perform cultural resources investigations to assess whether cultural resources are present that may rise to the level of significance of State Antiquities Landmark (SAL) status. The Texas Historical Commission (THC) has assigned Antiquities Permit number 8763 to the Project. Furthermore, project construction designs minimize impacts to Waters of the United States (WOTUS) crossed by the project, not meeting the minimum threshhold established under Section 404 of the Clean Water Act (CWA) for the requirement of a Pre-Construction Notification (PCN) to the United States Army Corps of Engineers (USACE).

\section{Project Description}

The Project consists of $2.2 \mathrm{~km}(1.4 \mathrm{mi})$ of new 42-in water transmission line installed within a permanently maintained utility easement that ranges in width from 8 to 19 meters ( $\mathrm{m} ; 26$ to 62 feet [ft]), from the proposed Redbud Pump Station at the eastern end of the Project to an existing 30-in transmission main near the proposed City of McKinney's Hardin Boulevard and Bloomdale Road extension intersection at the western end of the Project. The Project also includes temporary workspaces that will parallel the permanently maintained utility easement on one side and will range in width from 10 to $15 \mathrm{~m}$ (33 to $49 \mathrm{ft}$ ). The temporary workspaces will be intermittently utilized during Project construction for temporary staging areas and for bore pit excavations for boring beneath roadways and the Collin County Soil and Water Conservation District (SWCD) Site 17 Reservoir. Together, the permanently maintained utility easement and the temporary workspaces constitute the Project's area of potential effects (APE) (Appendix A, Figure 2). The Project's APE encompasses an area of 5.4 hectares (ha; 13.3 acres [ac]). Maximum excavation depth below ground surface throughout the Project is not expected to exceed $8 \mathrm{~m}(27 \mathrm{ft})$. Construction design modes include straight grade auger bore or tunneling, and open cut trenching.

From Community Avenue to the Project's northwestern terminus, the APE is located immediately adjacent to an area that has been subjected to a previous archaeological investigation (Appendix A, Figure 3). This area was previously surveyed during May 2017 by archaeologists from Burns \& McDonnell Engineering Company, as part of a cultural resources survey for the Bloomdale Road Extension project (Antiquities Permit No. 7946) (Fischbeck et al. 2017). The report documenting the results and recommendations from this survey has been submitted to and accepted by the THC. During that previous archaeological investigation, nine negative shovel tests (ST) were excavated. In addition, four backhoe trenches were excavated during exploratory geoarchaeological trenching. Two trenches were investigated on each side of the SWCD Site 17 
Reservoir, with no cultural material recovered. No newly recorded cultural resources were recorded within the APE of that previous investigation. The shovel tests and backhoe trenches from the investigation were excavated along a centerline that roughly parallels the current Project centerline at a distance of less than 25 $\mathrm{m}(82 \mathrm{ft})$. The Project's overlap along this area of the APE is $746 \mathrm{~m}(2,447 \mathrm{ft})$ long and covers an area of 1.9 ha $(4.7 \mathrm{ac})$.

\section{Project Location}

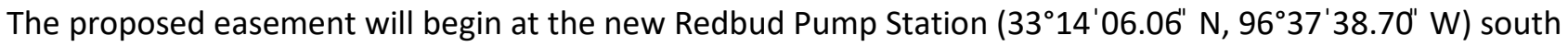
of Bloomdale Road, west of Redbud Boulevard/CR 273 (previously McLarry Drive), and continue in a west, northwesterly direction to its terminus, southeast of County Road 164 (3314'39.66" N, 96 38'16.921" W) (Appendix B, Figures 1-12). From the proposed Redbud Pump Station between Redbud Boulevard and Shawnee Drive, the line will extend east-west between Redbud Boulevard and James Pitts Drive (also CR 201), north of and parallel to Justice Road. At the intersection of Justice Road and James Pitts Drive $\left(33^{\circ} 14^{\prime} 07.18^{\prime \prime}\right.$ $\left.\mathrm{N}, 96^{\circ} 38^{\prime} 06.18^{\prime \prime} \mathrm{W}\right)$, the line will make an abrupt turn north, paralleling James Pitts Drive east, before angling

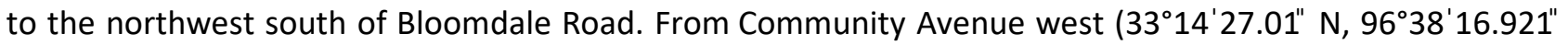
W), the main runs in a northwesterly direction south of the Natural Resources Conservation Service (NRCS) dam and west of the associated Collin County SWCD Site 17 Reservoir to an existing 30-in water transmission line northeast of South Hardin Boulevard, between CR 164 and Bloomdale Road (Appendix A, Figure 4). 


\section{Research Design}

\section{Background Research}

In anticipation of the Project, BGE conducted a background literature review of available data on the Texas Archeological Sites Atlas (TASA) to identify previous cultural resources investigations and previously recorded archeological and historic resource sites within an $805-\mathrm{m}(0.5-\mathrm{mi})$ study area. Additionally, a search of the National Park Service (NPS) online database was undertaken to determine whether historic properties listed in, or eligible for listing in, the National Register of Historic Places (NRHP) are located within the study area. Moreover, BGE reviewed available records from the Texas General Land Office Archival Resources Online database, and historic United States Geological Survey (USGS) 1929, 1954, 1958, and 1960 topographic maps available online at USGS Historic Topographic Map Explorer and historic 1952, 1957, 1968 and 1995 orthorectified aerial photographic imagery from USGS Historic Archive Earth Explorer for historic resources. Finally, BGE examined literature on the geoarchaeology of north-central Texas and the potential for deeply buried cultural material in reasonable context, or the likelihood of possessing geoarcheological potential (Abbott 2011).

\section{Survey Methodology}

Abbott's (2011) maps for the potential for surface and deeply buried archeological sites within the Texas Department of Transportation's Dallas District (Appendix A, Figures 5 and 6) were used to help determine ST intervals within the APE. These maps show that the potential for deeply buried archaeological sites is low, except for a narrow section of moderate potential just southeast of Community Avenue, another section of moderate potential on each side of the SWCD Site 17 Reservoir, and a section of moderate potential on the northwest terminus of the APE. No areas of high potential for deeply buried archaeological sites exist within the APE. However, the map depicting the potential for surface archaeological sites does show significant portions of the APE within areas of moderate potential, as well as the area where the APE turns northwest, just south of Bloomdale Road, to be of high potential. Based on this map, the high potential area was shovel

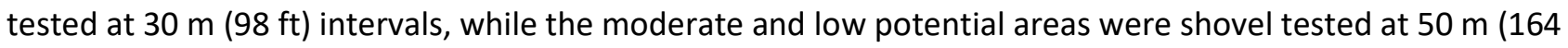
$\mathrm{ft}$ ) intervals, along one transect located in the Project's centerline.

STs were excavated whenever there was less than 30 percent ground surface visibility, except on slopes greater than 20 percent, or placed at the discretion of the lead archeologist, to the bottom of Holocene deposits, whenever possible. Shovel tests measured $30 \mathrm{~cm}$ (12 in) on a side and were excavated in $10 \mathrm{~cm}(4$ in) arbitrary levels with sediments screened through $1 / 4$-in mesh hardware cloth. Clay matrices that could not be screened were finely sorted by hand or troweled and visually inspected for cultural material. All areas of the easement that have undergone significant disturbance, as in asphalted surfaces, concrete streets, sidewalks, parking lots, and driveways, were not shovel tested but were thoroughly photo documented.

For each shovel test, the location, maximum depth, soil strata, color and texture of soil matrices, aided by Munsell Soil Color Book (Munsell Color Company 2000), and the absence or presence of cultural material were recorded on BGE shovel test forms. Positive shovel tests and surficial scatters of cultural material were considered potential sites. All positive shovel tests were subject to a program of site definition. Site definition 
consisted of systematic shovel testing to determine the horizontal and vertical site extent. Typically, site boundaries are defined by a series of shovel tests along transects radiating in the four cardinal directions, or if more appropriate, along perceived major and minor axes. The first positive shovel test was utilized as datum with subsequent site shovel tests placed at 10-m (33-ft) intervals. Sites were mapped using a program of compass and tape, and a Samsung Galaxy Tab Active2 data collector and Trimble R1 GNSS Receiver. Site field forms included site shovel test (SST), site sketch maps, photographs accompanied by photo logs, and TexSite Archeological Site Form. All cultural material located on private land was recorded in the field but not collected.

The project will utilize straight grade auger bore or tunneling constriction methodology to bore under roads, water features, and existing pipelines. STs will be excavated at the location, or within a short distance, of the location where bore pits will be excavated. If these shovel tests were unable to reach deeper soils with potential to contain undisturbed archaeological deposits, a program of systematic deep prospection will be implemented. This program will follow proposed Council of Texas Archeologists (CTA) guidelines for mechanical prospection, and may include hand augering, mechanical augering, or mechanical trenching, as permitted by the local environment.

The field effort was executed by professional archeologists under the direction of the Principal Investigator to ensure effective implementation of established procedures. This investigation was performed in compliance with the NHPA, the procedures of the USACE 33 C.F.R. 325 Appendix C--Procedures for Protection of Historic Properties, Advisory Council on Historic Preservation (36 C.F.R. Part 800-Protection of Historic Properties), in conjunction with the guidelines set forth by the THC and the CTA. 


\section{Results}

\section{Records Review}

The review of available data in the TASA indicated that no archaeological sites, historic properties, historic districts, buildings, or structures, included in, or eligible for inclusion in, the NRHP, Texas State Historical Markers, SALS, cemeteries, or museums were located within or immediately adjacent to the Project's APE. A review of historic topographic maps and aerial imagery was conducted to determine if structures were present within or adjacent to the APE. A 1952 USGS aerial photograph shows a set of structures abutting or partially inside the APE (Appendix A, Figure 7). The 1960 McKinney West USGS 15-Minute Topographic Quadrangle map (Appendix A, Figure 8) depicts the same structures, as well as other structures in close proximity to the APE. Finally, a 1968 USGS aerial photograph (Appendix A, Figure 9) still shows the structures observed on the 1952 aerial photograph, as well as several other structures outside the APE.

The TASA records revealed that there have been eight previous cultural resources surveys conducted within the study area (Appendix A, Figure 10), three of which are intersected by the APE (Table 1). Although no archeological sites have been recorded within the APE, two previously recorded historic-period sites (41COL278 and 41COL157), one cemetery, and one historical marker associated with the cemetery (Marker No. 6182 ) are located within the study area. Site $41 \mathrm{COL} 278$ is located approximately

and site 41COL157 is located

approximately

Site 41COL278 has been determined Ineligible for inclusion in the NRHP (THC \& TARL 2019). Site 41COL157 is of Undetermined eligibility for inclusion in the NRHP (THC \& TARL 2019). The historical marker located within the study area is associated with the McLarry Cemetery. The McLarry Cemetery is situated approximately

Site 41COL278, also known as Redbud Cistern Site, was identified

As recorded by Davis (2017), the cistern was crafted from bedrock with natural shales providing enough seal to hold water to a depth of over $2 \mathrm{~m}(6.5 \mathrm{ft})$. Along the north edge of the cistern, a small concrete pad measuring $75 \mathrm{~cm}$ (29 in) in width by $97 \mathrm{~cm}$ (38 in) in length and $41 \mathrm{~cm}$ (16 in) thick paralleled the opening. The opening was described as "roundish" and measured $130 \mathrm{~cm}$ (51 in) north-south by $150 \mathrm{~cm}$ (59 in) east-west. Two handmade brick fragments served as the only cultural material remaining at the site (THC \& TARL 2019).

Site 41COL157 is situated and consisted of a 53-cm (21-in)

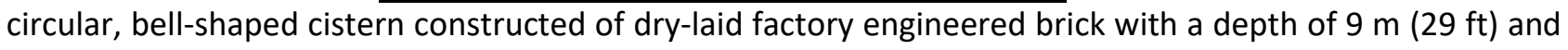
surficial scatter of historic material culture. According to TASA, recorded cultural material included a marble, tobacco can, plate shard, bottle glass, ceramic china shards, and a condensed milk can. Collectively, the site

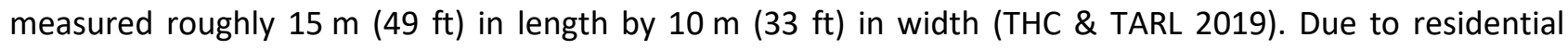
development, this site is no longer extant. 
The McLarry Cemetery, with its associated Historical Marker No. 6182, was initially used for a single burial of an infant in 1851. The land on which the cemetery is now situated was donated by Mary Virginia Dunn McLarry and her father Robert A. McLarry (THC \& TARL 2019), as a public cemetery for the early pioneers of Peters Colony (1841-1859) and Wilmeth Settlement (1848-1918) (Texas General Land Office n.d.). Currently, the cemetery serves the descendants of the early settlers of central Collin County. When the Republic of Texas (1836-1846) was established, it assumed responsibility for its public domain lands and sought to attract settlers for the purpose of colonizing unappropriated and vacant lands of the Republic. The earliest regions to be occupied comprised the southeastern Gulf Coast, lower Colorado and Brazos river valleys and eastern piney woods. During the 5th Congress of the Republic of Texas, the legislature, in an effort to expand its tax base and promote settlement in North Texas, adopted the Empresario model used by Mexico, which authorized the establishment of the "Land and Colonization Law "of 1841 (Texas General Land Office n.d.). The Peters Colony was the earliest Empresario authorized under the law of 1841. The settlement of Wilmeth, named after J.B. Wilmeth, the first teacher to settle in the vicinity of the project, offered resident children classes in a log cabin school house that was located on land originally granted to Tola Dunn, a Peters Colony resident in 1843 (Texas General Land Office n.d.). 
Table 1: Cultural Resources Investigations within 805 m (0.5 mi) Study Area

\begin{tabular}{|c|c|c|c|c|}
\hline Atlas \# & Description & Location & Survey Results & Reference \\
\hline - & $\begin{array}{l}\text { City of McKinney-Phase I survey } \\
\text { augmented by deep trenching for } \\
\text { the Bloomdale Road Extension } \\
\text { (Permit Number 7946) }\end{array}$ & $\begin{array}{l}\text { Parallel to and } \\
\text { overlapping the } \\
\text { northwesternmost } \\
\text { section of the APE }\end{array}$ & $\begin{array}{l}\text { No archeological } \\
\text { resources } \\
\text { identified; } 5 \text { non- } \\
\text { archeological } \\
\text { historic resources } \\
\text { were recorded }\end{array}$ & $\begin{array}{l}\text { Burns and } \\
\text { McDonnell } \\
\text { (2017) }\end{array}$ \\
\hline 8400000843 & City of Irving-Phase I survey & $\begin{array}{l}\text { Running east to west and } \\
\text { intersecting the APE } \\
\text { approximately } 80 \mathrm{~m} \mathrm{(262} \\
\text { ft) south of Bloomdale } \\
\text { Road }\end{array}$ & $\begin{array}{l}\text { No resources } \\
\text { identified }\end{array}$ & $\begin{array}{l}\text { City of Irving } \\
\text { (1999) }\end{array}$ \\
\hline 8500013129 & $\begin{array}{l}\text { TxDOT-Phase I survey for US } 75 \\
\text { between Spur } 399 \text { and SH } 121\end{array}$ & $\begin{array}{l}\text { North-south along North } \\
\text { Central Expressway. } \\
\text { Intersecting the APE close } \\
\text { to its eastern terminus }\end{array}$ & $\begin{array}{l}\text { No resources } \\
\text { identified }\end{array}$ & Owen (2003) \\
\hline 8500080459 & $\begin{array}{l}\text { Lockwood, Andrews \& Newman, } \\
\text { Inc.-Phase I survey for the proposed } \\
\text { Redbud Pump Station } 794 \text { PP } \\
\text { Transmission Waterline ROW. }\end{array}$ & $\begin{array}{l}200 \mathrm{~m}(656 \mathrm{ft}) \text { east of the } \\
\text { APE's eastern terminus }\end{array}$ & $\begin{array}{l}\text { No resources } \\
\text { identified }\end{array}$ & Gilliland (2017) \\
\hline 8500012242 & $\begin{array}{l}\text { NRCS--Phase I survey for } \\
\text { rehabilitation of floodwater } \\
\text { retarding structure }\end{array}$ & $\begin{array}{c}215 \mathrm{~m}(705 \mathrm{ft}) \text { north of } \\
\text { the APE }\end{array}$ & $\begin{array}{l}\text { No resources } \\
\text { identified }\end{array}$ & Sanders (2005) \\
\hline 8500015491 & $\begin{array}{l}\text { City of McKinney--Phase I for } \\
\text { Bloomdale Road extension and } \\
\text { scraping outside McLarry Cemetery }\end{array}$ & $\begin{array}{c}460 \mathrm{~m}(1,509 \mathrm{ft}) \text { north of } \\
\text { the APE's eastern } \\
\text { terminus }\end{array}$ & $\begin{array}{l}\text { No resources } \\
\text { identified }\end{array}$ & Tine (2008) \\
\hline 8500080218 & $\begin{array}{l}\text { NTMWD--Phase I for North } \\
\text { McKinney Pipeline }\end{array}$ & $\begin{array}{l}205 \mathrm{~m}(673 \mathrm{ft}) \text { east of the } \\
\text { APE's eastern terminus }\end{array}$ & $\begin{array}{l}\text { No resources } \\
\text { identified }\end{array}$ & $\begin{array}{l}\text { Koszarek and } \\
\text { Morgan (2017) }\end{array}$ \\
\hline 8500080008 & $\begin{array}{l}\text { City of McKinney--Phase I for } \\
\text { Redbud Pump Station }\end{array}$ & & $\begin{array}{c}41 C O L 278 \\
(85027801)\end{array}$ & Davis (2016) \\
\hline
\end{tabular}

NOTE: Shaded rows indicate investigations that intersect the Project APE.

\section{Field Investigation}

Between February 6 and 7, and on April 10 and November 17,2019, BGE conducted an intensive pedestrian survey augmented by shovel testing on the entire APE. BGE archeologists excavated 70 STs within the Project's APE (Appendix A, Figure 11). BGE archaeologists also excavated five STs within a previously considered Project alignment, just south of Bloomdale Road. Five attempted shovel tests were not excavated due to heavy disturbance or inundation and were recorded as surface inspections. Shovel test were excavated to an average depth of $37.5 \mathrm{~cm}$ (12.6 in) and were terminated at sterile clays at depths up to $60 \mathrm{~cm}$ (24 in).

This investigation determined that there are no areas within the APE where shovel testing was an inadequate methodology to reach deeper soils with potential to contain undisturbed archaeological deposits. This 
includes the areas where the bore pits will be excavated. Every ST reached sterile clays before reaching one meter in depth - the maximum depth reachable by a ST. This is further supported by the lack of areas of high potential for deeply buried archaeological sites (Abbott 2011) within the APE (Appendix A, Figure 6). In addition, as mentioned in the Project Description subsection above, from Community Avenue to the Project's northwestern terminus, the APE is located immediately adjacent to an area that has been subjected to a previous archaeological investigation. In May 2017, Burns \& McDonnell conducted a pedestrian survey augmented by shovel testing and deep testing for the City of McKinney under Antiquities Permit Number 7946. The survey was performed for the Bloomdale Road Extension Project, which will connect existing Bloomdale Road to County Road 164 (Fischbeck et al. 2017). During that previous archaeological investigation, four backhoe trenches were excavated during exploratory geoarchaeological trenching. Two trenches were investigated on each side of the SWCD Site 17 Reservoir (Appendix A, Figure 11-b), with no cultural material recovered. Each trench was excavated to a depth of the maximum extent of the backhoe bucket arm; approximately 2.4 meters $(\mathrm{m})$ (8 ft). Soils were predominantly silty clay and included redoximorphic features at depth. During excavation, trench back-dirt was visually inspected, and trench walls were examined for the presence of archeological deposits. Stratigraphic profiles were completed for each trench. Trenches 1 and 2 terminated in a 90-centimeter $(\mathrm{cm})(35-i n)$ thick layer of mottled clay with caliche inclusions. Trench 3 terminated in a layer of mottled clay approximately $40 \mathrm{~cm}$ (16 in) thick. Trench 4

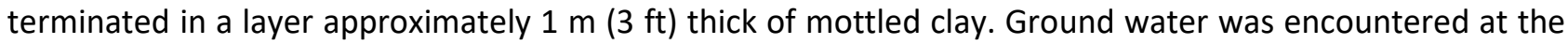
bottom of Trench 4 (Fischbeck et al. 2017). The report documenting the results and recommendations from this survey has been submitted to and accepted by the THC.

The backhoe trenches from the previous investigation were excavated along a centerline that roughly parallels the current Project centerline at a distance of $25 \mathrm{~m} \mathrm{(82} \mathrm{ft)} \mathrm{on} \mathrm{the} \mathrm{northwest} \mathrm{side} \mathrm{of} \mathrm{the} \mathrm{Reservoir}$

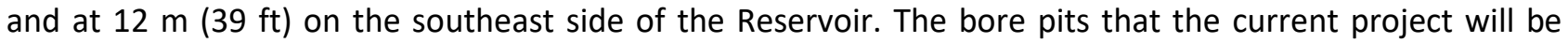
excavating at each side of the Reservoir will be between 11 and $12 \mathrm{~m} \mathrm{(} 35$ and $38 \mathrm{ft}$ ) deep, to accommodate for the straight grade auger bore or tunneling construction method.

The area around the Reservoir, including where the bore pits will be excavated, has been classified as having moderate to negligible potential for containing deeply buried archaeological deposits (Abbott 2011). The four trenches excavated by the previous archaeological investigation reached pre-Holocene sterile soils and were excavated to the maximum depth allowed by typical mechanical equipment used for archaeological trenching (Fischbeck et al. 2017). BGE believes that additional trenching in the area will not yield different results from the ones obtained during the previous archaeological investigation and that additional trenching is unnecessary. Therefore, BGE believes that portion of the Project has already been adequately investigated for deep deposits.

one ST was positive. This positive ST was delineated and assigned site number 41COL324. Outside from site 41COL324, all other STs were negative, and BGE archaeologists did not encounter any other archaeological features, standing structures, or historic sites during the pedestrian survey conducted across the entire APE. 


\section{Site Description}

Site 41COL324 is situated

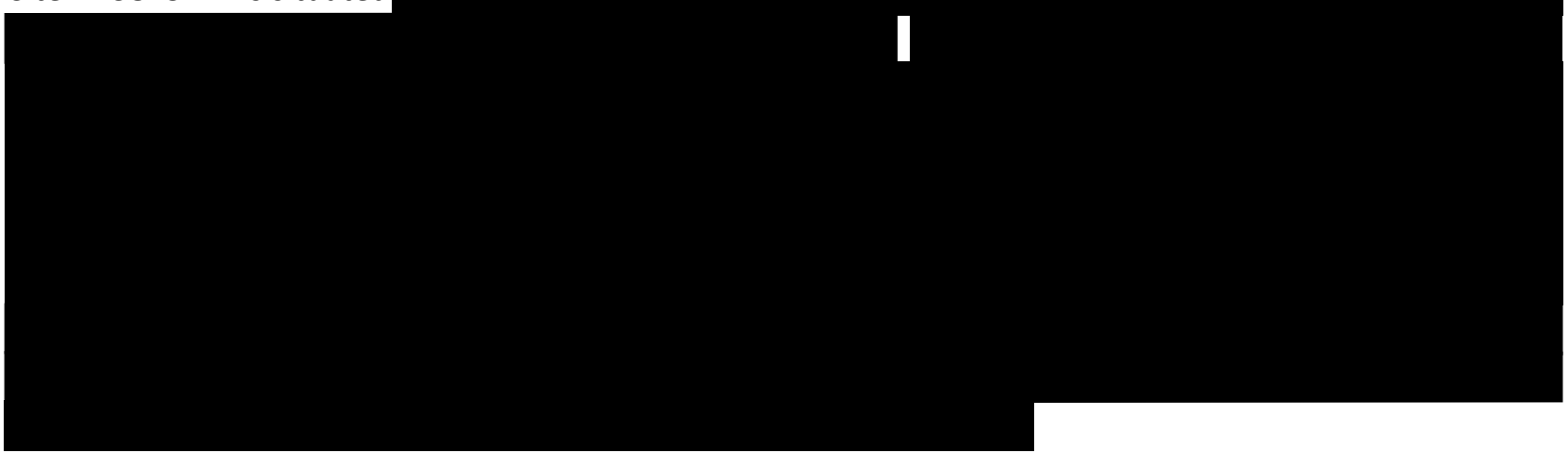

SST1 was positive with 11 historic artifacts. These consisted of five clear glass fragments, two of which exhibit a violet/amethyst tint, four ceramic fragments, one ceramic grate rim fragment, and one fragment of plastic material (Appendix B, Figures 18-23). All were excavated from the uppermost 35 centimeters below surface (cmbs). This positive ST was delineated by excavating two consecutive negative STs, at $10 \mathrm{~m}$ (33 ft) intervals, radiating in cardinal directions from the positive ST. To the north, south, and east, the two consecutive ST were excavated with negative results. To the west, only one negative ST was excavated (Appendix A, Figure 14). Two sparse surface scatters of solarized glass fragments were recorded just east of the centerline, along a two-track road. In addition, two wells were recorded, also east of the centerline along the two-track road. These wells were dug into the bedrock and a brick enclosure was constructed from ground level to the bedrock - approximately $30 \mathrm{~cm}$ (12 in) deep - to prevent soil infilling. Polyvinyl chloride (PVC) piping and fittings protrude from under the brick enclosure (Appendix B, Figure 17).

Two negative SSTs were excavated in every cardinal direction from the surface scatters and from the wells. In total, 26 SSTs were excavated in the vicinity of 41COL324. These SSTs were excavated to an average depth of $46 \mathrm{cmbs}$ (18 in) through clay and clay loam soils. All were terminated at basal clay or at compact, manually unexcavatable clay (Table 2 ).

Table 2: SSTs Excavated at 41COL324

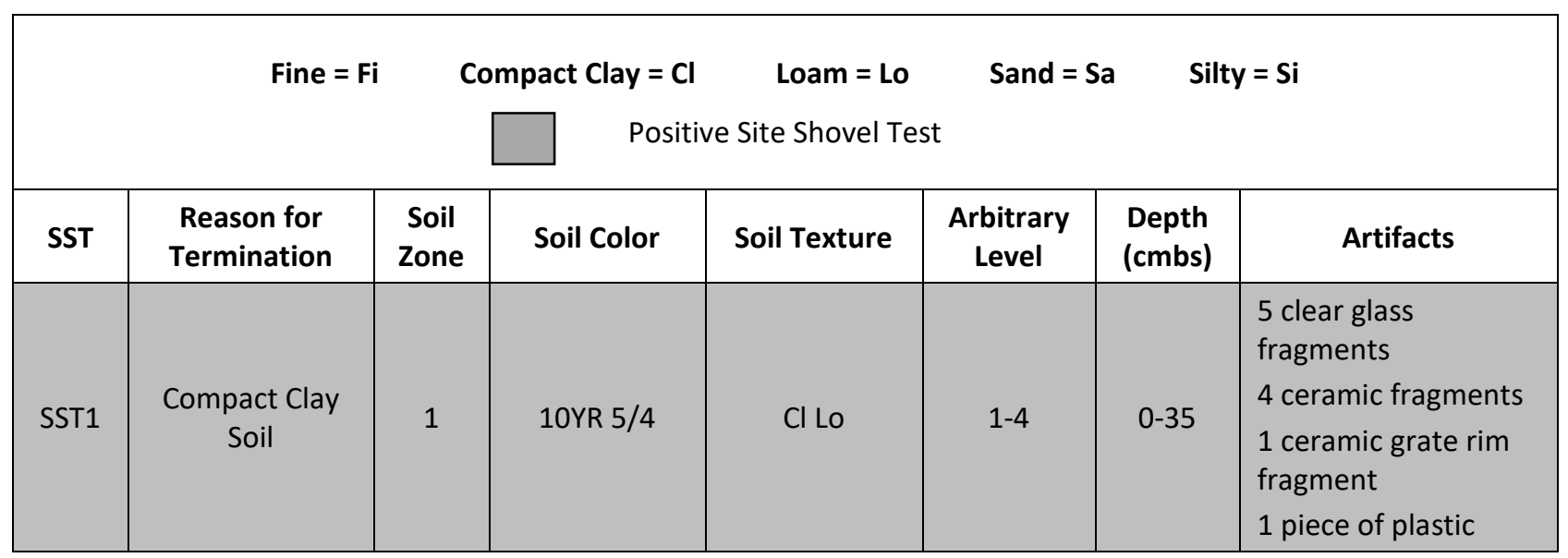




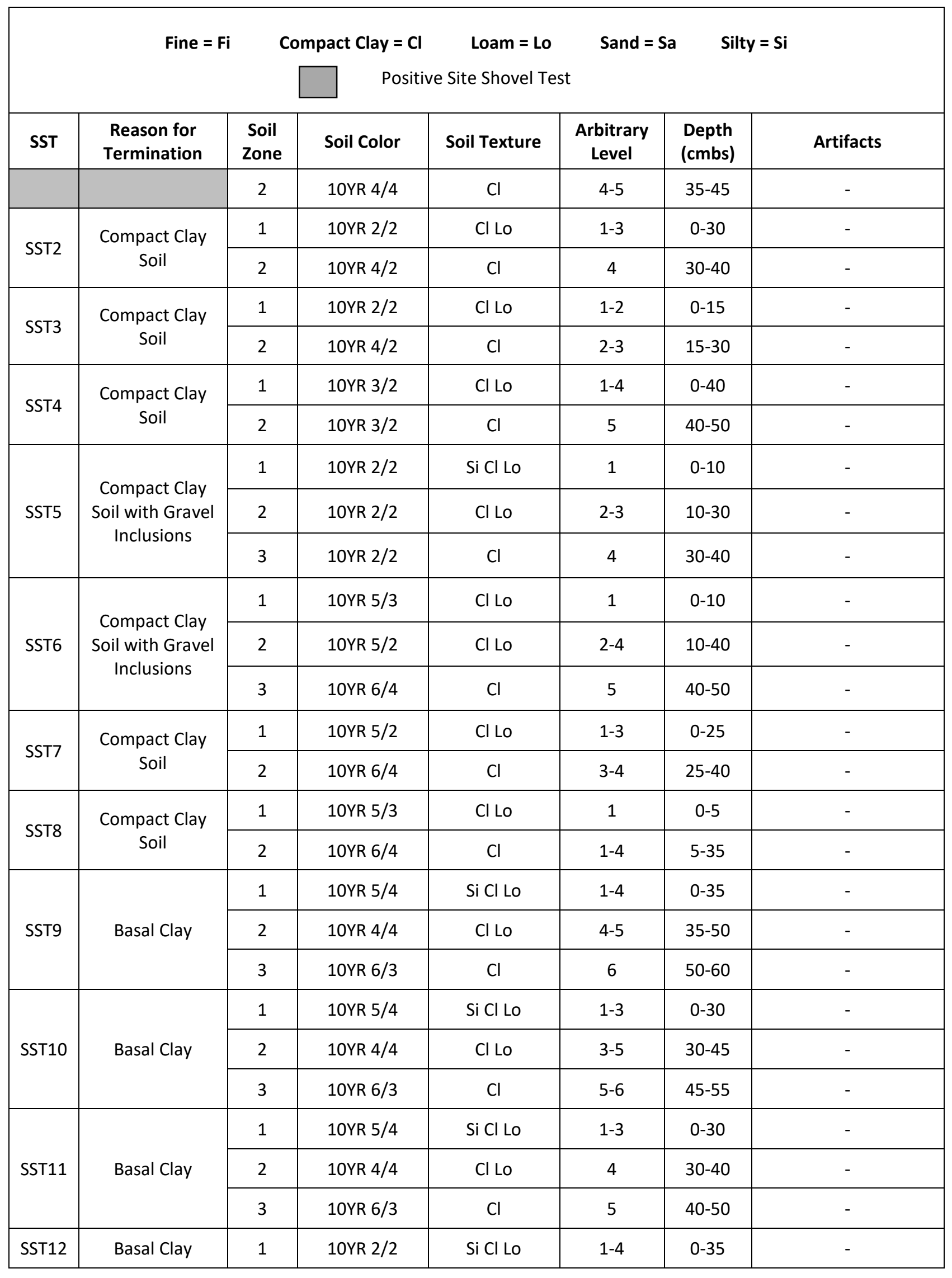




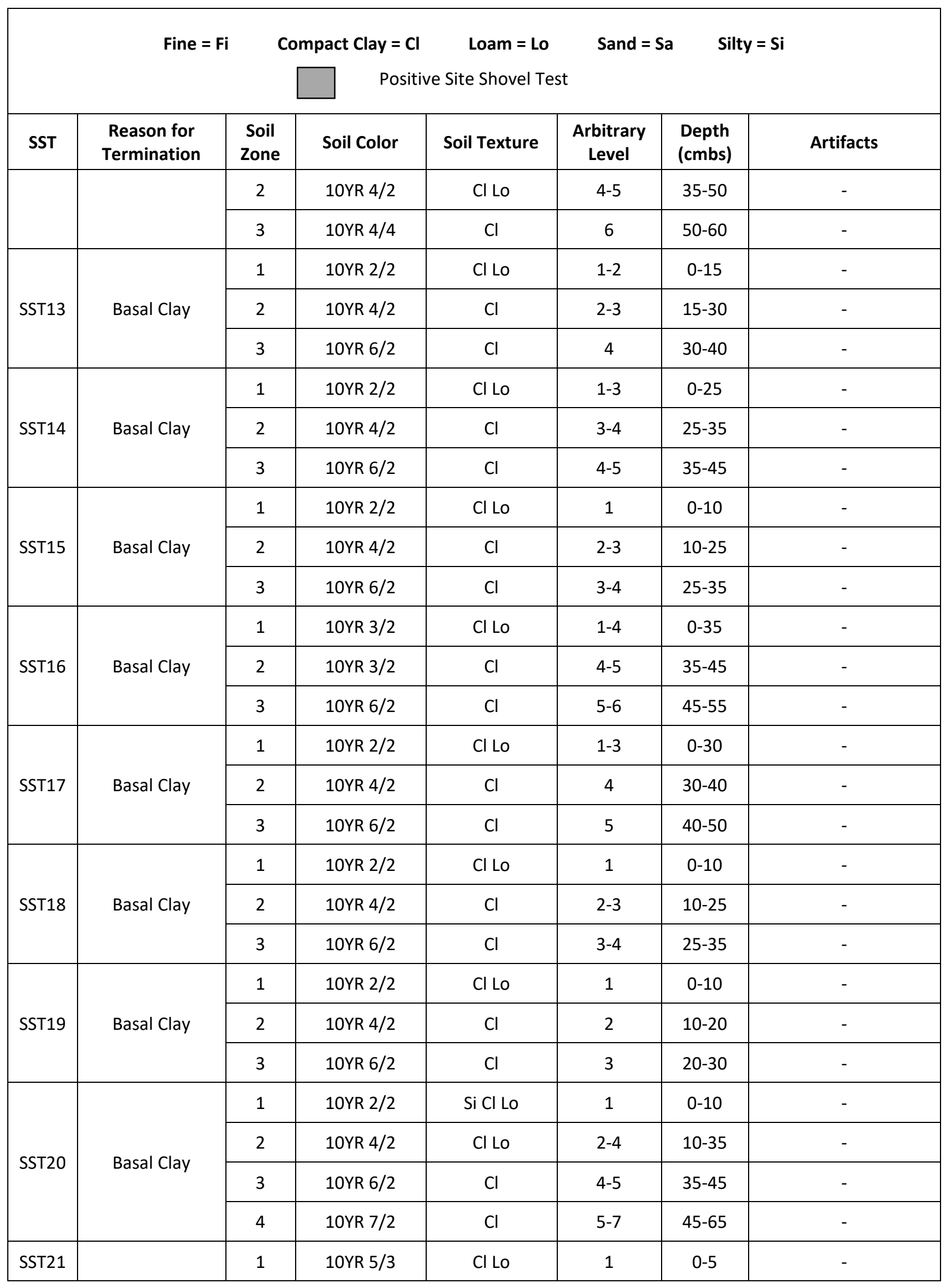




\begin{tabular}{|c|c|c|c|c|c|c|c|}
\hline & \multirow{2}{*}{\multicolumn{2}{|c|}{ Fine $=\mathbf{F i}$}} & Compact Clay $=\mathrm{C}$ & Loam $=\mathrm{LC}$ & \multicolumn{2}{|c|}{ Sand $=$ Sa } & Silty $=\mathbf{S i}$ \\
\hline & & & & e Site Shovel T & & & \\
\hline \multirow[t]{2}{*}{ SST } & $\begin{array}{l}\text { Reason for } \\
\text { Termination }\end{array}$ & $\begin{array}{c}\text { Soil } \\
\text { Zone }\end{array}$ & Soil Color & Soil Texture & $\begin{array}{c}\text { Arbitrary } \\
\text { Level }\end{array}$ & $\begin{array}{l}\text { Depth } \\
\text { (cmbs) }\end{array}$ & Artifacts \\
\hline & $\begin{array}{l}\text { Compacted, } \\
\text { disturbed soil } \\
\text { near road }\end{array}$ & 2 & 10YR 6/4 & $\mathrm{Cl}$ & $1-5$ & $5-45$ & - \\
\hline \multirow{2}{*}{ SST22 } & \multirow{2}{*}{$\begin{array}{l}\text { Compacted, } \\
\text { disturbed soil } \\
\text { near road }\end{array}$} & 1 & 10YR 5/3 & Cl Lo & 1 & $0-5$ & - \\
\hline & & 2 & 10YR 6/4 & $\mathrm{Cl}$ & $1-5$ & $5-45$ & - \\
\hline \multirow{3}{*}{ SST23 } & \multirow{3}{*}{ Basal Clay } & 1 & 10YR 5/3 & Cl Lo & 1 & $0-10$ & - \\
\hline & & 2 & 10YR 5/2 & Cl Lo & $2-4$ & $10-35$ & - \\
\hline & & 3 & 10YR 6/4 & $\mathrm{Cl}$ & $4-5$ & $35-45$ & - \\
\hline \multirow{2}{*}{ SST24 } & \multirow{2}{*}{$\begin{array}{c}\text { Compact Clay, } \\
\text { Gravel }\end{array}$} & 1 & 10YR $4 / 3$ & Cl Lo & 1 & $0-5$ & - \\
\hline & & 2 & 10YR 6/4 & $\mathrm{Cl}$ & $1-4$ & $5-40$ & - \\
\hline \multirow{3}{*}{ SST25 } & \multirow{3}{*}{ Basal Clay } & 1 & 10YR 4/4 & Si Cl Lo & $1-4$ & $0-35$ & - \\
\hline & & 2 & 10YR 5/4 & Cl Lo & $4-5$ & $33-45$ & - \\
\hline & & 3 & 10YR $6 / 3$ & $\mathrm{Cl}$ & $5-6$ & $45-60$ & - \\
\hline \multirow{2}{*}{ SST26 } & \multirow{2}{*}{ Basal Clay } & 1 & 10YR 4/4 & Cl Lo & 1 & $0-10$ & - \\
\hline & & 2 & 10YR 6/4 & $\mathrm{Cl}$ & $2-5$ & $10-45$ & - \\
\hline
\end{tabular}

\section{Artifact Analysis}

Site 41 COL324 is located therefore all artifacts were documented in the field and not collected. Prior to photo documentation and recordation, artifacts were rinsed, sorted and preliminarily analyzed. Artifacts consist of clear glass fragments $(n=5)$, three of which exhibited significant patination (weathering/decay) (Munsey 1970), while two reflected a violet/amethyst solarized hue (known also as sun-colored). Amethyst tinted glass is the result of the use of manganese as a decolorization agent; when exposed to sunlight, the manganese causes the glass to turn a distinctive shade of violet (Lockhart 2006). The next most frequent artifact type represented decorated, pale blue-green glazed whiteware $(n=4)$, two shards of which fit together (Miller 2015; Stelle 2011). All ceramic shards were absent a makers-mark. Of the two remaining materials, there was a single ceramic grate rim fragment, possibly from a gas operated, cast iron Radiantfire fireplace burner $(n=1)$ (Humphrey 2015) and a pearled, pale yellow colored cast resin fragment, possibly Bakelite ( $n=1$ ) (Davidov and Redington 1988) (Appendix B, Figures 18 - 23). Although limited in number, the range of material suggests the site was a residential locus from the late $19^{\text {th }}$ to the mid-20 th century (Table 3 ). 
Table 3: Artifacts from site 41COL324

\begin{tabular}{|c|c|c|l|}
\hline Material & Count & Date Range & \multicolumn{1}{c|}{ Discussion } \\
\hline Clear glass & 5 fragments & Post 1889 & $\begin{array}{l}\text { Machine-made. Container body fragment. Vertical side mold } \\
\text { seam. Iridescent patina. The date range presented herein is an } \\
\text { estimate as there was an insufficient amount of the container } \\
\text { to exact a more accurate date. Two fragments reflected a } \\
\text { violet/amethyst solarized hue (known also as sun-colored), } \\
\text { including One beaded-rim vase fragment. }\end{array}$ \\
\hline Whiteware & $\begin{array}{c}\text { 4 shards } \\
\text { Ceramic }\end{array}$ & $\begin{array}{c}\text { Early to mid-19th } \\
\text { century; pale blue- } \\
\text { green glaze on } \\
\text { fiesta ware to 1940 }\end{array}$ & $\begin{array}{l}\text { Monochrome, pale blue-green glazed ceramic ware. Circular } \\
\text { rim shard exhibits embossed basket weave pattern on interior } \\
\text { saucer brim. Crackling present. All shards are most likely from } \\
\text { the same vessel. }\end{array}$ \\
\hline Cast resin & 1 fragment & $\begin{array}{l}\text { Amber colored ceramic fragment, possibly a heater } \\
\text { grate/panel rim fragment from a Humphrey, cast iron } \\
\text { Radiantfire gas fireplace burner (heater). }\end{array}$ \\
\hline
\end{tabular}

\section{Archival Research}

Chain of title research for the property where 41COL324 is located was conducted by the Land Surveying department at BGE, from official public records of Collin County, Texas. Table 4 shows the results of this research, listing the property owners from 1856 to 1983. BGE archaeologists conducted historical background research on each of the landowners with the purpose of determining if site 41COL324 can be potentially "associated with the lives of significant persons in our past", as per Criteria B of the National Register Criteria for Evaluation, set forth by the National Park Service (National Park Service 2002).

Table 4: Owners of Property where Site 41COL324 is Located

\begin{tabular}{|c|c|}
\hline Property Owner & Years Owned \\
\hline & \\
\hline & \\
\hline & \\
\hline & \\
\hline & \\
\hline & \\
\hline & \\
\hline & \\
\hline & \\
\hline & \\
\hline & \\
\hline
\end{tabular}




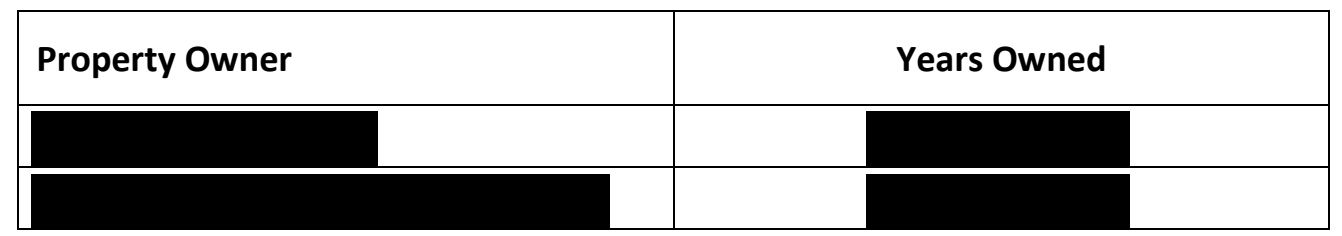

Title research for this property lists the original occupant as in 1856 by Texas Governor Elisha M. Pease, following who was granted the land American War, from 1846 to 1849 . enlisted in 1846 and was immediately granted the position of First Lieutenant to lead companies composed of men primarily from Grayson and Collin County (Gough n.d.) The 1860 Census lists him and his family as farmers (USDC 2019). In 1863, the property was purchased by was a member of Approximately $3.7 \mathrm{~km}$ (2.3 mi) from the surveyed property still stands a $\quad$ amily house, constructed in 1925 , unaltered aside from a renovation that occurred within a decade of the original construction (Michero 2019). The following landowners were from November 1887 to June 1888, and from June 1888 to September 1888. It can be assumed that these owners were investors or real estate agents due to the short period of time this property was under their possession. In September of 1888 the property was purchased by 2019) In 1905 the property was purchased by , who was a farmer, according to the 1900 census (USDC

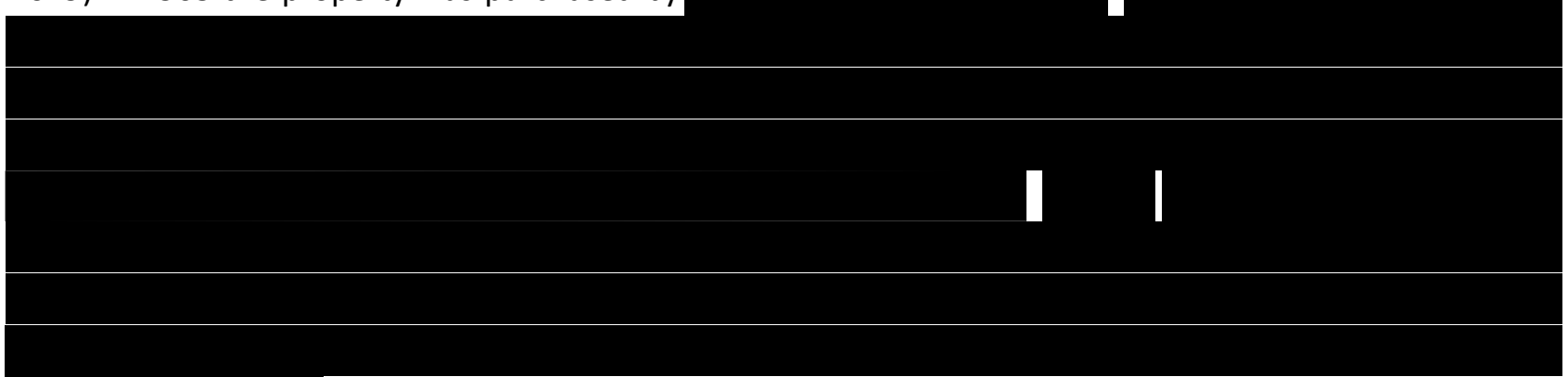

According to the 1910 Census he and his wife were farmers. He died in 1907, and records show that this property and all his belongings were willed to his wife, who later died in 1917, one year after she sold the property (USDC 2019). In 1916 the property was purchased by The 1930 Census lists as a housewife and her husband s a physician (USDC 2019) In 1938 the property was purchased by , who was a railroad worker, according to the 1940 Census (USDC 2019) . In 1943 the property was purchased by who was a WWI veteran, and a farmer. was a WWI veteran as well, and also served as the county attorney in 1866 .

It is now known if this property was bought because of this affiliation (USDC 2019; Biographical Encyclopedia of Texas 1880). In 1958 the property was purchased by who was a WWII veteran. He was the second-generation owner of

, which was founded in 1918, following his late father and uncle. $\square$ also served as a chairman of the Dallas Planning Commission and was a past president of the Texas Heavy Municipal and Utility Chapter of the Associated General Contractors of America (The Dallas Morning News 
2013). In 1968 the property was purchased by

and later sold in December of 1969. It is assumed that this was another real estate venture. In 1969 the property was purchased by who was a WWI veteran, retired lawyer, and genealogist that co-authored a book about his family lineage (The Dallas Morning News 1971). In June of 1969,

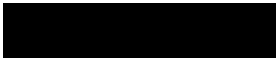

In summary, this research did not result in information that indicates site 41COL324 is potentially "associated with the lives of significant persons in our past", and as such does not meet Criteria B of the National Register Criteria for Evaluation. This research also did not result in information that indicates the property can be associated with a significant event and, therefore, does not meet Criterion A of the National Register Criteria for Evaluation.

Site 41COL324 appears to represent a historic-period refuse midden related to a late nineteenth or early twentieth century farmstead or other domestic occupation. Artifacts were restricted to the upper $35 \mathrm{cmbs}$ (14 in) of soil, a depth that was commonly subjected to human disturbances, such as plowing. Due to the frequently flooded nature of the area, it is also possible that the artifacts were secondarily deposited. The location of the two wells indicate a structure was likely standing nearby at some point. Based on the artifacts encountered, the lack of standing structures, and the results of the chain of title research, BGE archeologists conclude that the portion of site 41COL324 within the Project's APE lacks potential for future study and does not meet any criteria for evaluation that would make it potentially eligible for listing on the NRHP. Therefore, BGE recommends that 41 COL324 be determined as Ineligible for inclusion in the NRHP, and the project be allowed to proceed without further consultation in the vicinity of 41COL324. Furthermore, because the two wells are located BGE recommends that the City avoids impacts to those two wells during construction activities, by placing high visibility protecting fencing around them to avoid heavy equipment tracking through the area. 


\section{Summary and Management Recommendations}

At the request of the City, BGE conducted an intensive pedestrian survey augmented by shovel testing of the Project. The intensive survey was conducted in support of the City's requirements under the Texas Antiquities Code and the Texas Natural Resources Code Chapter 26 'Rules of Practice and Procedure' for the Antiquities Code of Texas'.

The field investigation, which was conducted February 6-8, and April 10, 2019, was overseen by personnel meeting the Secretary of the Interior Professional Qualification Standards in Archaeology, and according to field and reporting standards established by the THC and the CTA. As such, the investigation involved both a pedestrian survey component, as well as a shovel testing protocol. As a result of the investigation, one new cultural resource site was identified, which was assigned trinomial 41COL324 by TARL.

Site 41COL324 appears to represent a historic-period refuse midden related to a late nineteenth or early twentieth century farmstead or other domestic occupation. It consists of a shallow subsurface deposit of historic artifacts, all excavated from one ST, as well as two discrete areas of sparse surface scatters of historic artifacts. Two wells are also located within the site. No standing structures remain. Archival research on the owners failed to associate the property with a person of historical significance. As a result, BGE archeologists conclude that 41COL324 lacks potential for future study and does not meet any criteria for evaluation that would make it potentially eligible for listing on the NRHP. Therefore, BGE recommends that portions of 41COL324 located within the Project's APE be determined as Ineligible for inclusion in the NRHP, and the project be allowed to proceed without further consultation in the vicinity of 41COL324. Furthermore, because the two wells are located

BGE recommends that the City avoids unintended impacts to these features during construction activities. BGE recommends placing high visibility protective fencing around them to ensure heavy equipment tracking through the area does not inadvertently impact these features.

Finally, if during construction, intact cultural resource deposits are inadvertently discovered during grounddisturbing activities, all activities at that location must cease immediately and the field supervisor contacted. The supervisor will then contact a professional archeologist that meets the Secretary of the Interior Professional Qualification Standards to assess the findings. Following assessment, the archeologist will then contact the THC pursuant to 36 C.F.R. Part 800.13-Post review discoveries:

If historic properties are discovered or unanticipated effects on historic properties found after the agency official has completed the Section 106 process without establishing a process under paragraph (a) of this section, the agency official shall make reasonable efforts to avoid, minimize or mitigate effects to such properties. (13(b)). 


\section{References}

Abbott, J. T.

2011 Geoarcheolgogy of North-Central Texas. Austin: Texas Department of Transportation (TxDOT), 16-23.

Davidov, C., and G. Redington

1988 The Bakelit Jewelry Book. Dawes, New York: Abbeville Press.

Davis, Cody S.

2017 Archaeological Survey of the Proposed City of McKinney Redbud Pump Station Collin County, Texas. Cultural Resources Report 2017-01, Richardson: AR Consultants, Inc.

Eyre, R.

1980 Forest Cover Types of the United States and Canada1980. Edited by F.H. Eyre. Washinton, D.C.: Society for American Foresters.

Fischbeck, S., C. Rucker, B. Harris.

2017 City of McKinney Bloomdale Road Extension Project CIP \#4227 McKinney, Texas. ACT Permit Number 7946. Dallas, Texas: Burns \& McDonnell Engineering.

Gough, Joy

n.d. Collin County History. Accessed October 24, 2019. https://www.collincountyhistory.com.

Harvey, K.G.

2012 "Who Needs a Plow-Zone? Using a Common Site Mapping Method in a New Way at the Silvermale Site (21GD03)." All Theses, Dissertations, and Other Capstone Projects. Mankato, Minnesota: Minnisota State University. 331.

Humphrey

2015 "Humphrey History 1901 - Today." Kalamazoo, Michigan: Humphrey Products Corporation. Accessed March 12, 2019. https://www.humphrey-products.com/content/humphrey-history-1901today.

Lockhart, B.

2006 "The Color Purple: Dating Solarized Amethyst Container Glass." Historical Archaeology (Federation of Historical Bottle Collectors) 40 (2): 45-56.

Michero, Tom

20191108 Tucker Street, Jesse Graves House. Accessed October 24, 2019.

http://mckinneyhistory.com/home-histories/1108-tucker/.

Miller, G. L.

2015 "Classification and Economic Scaling of 19th Century Ceramics." Historical Archaeology (Society for Historical Archaeology) 14: 1-40. 


\section{Munsell Color Company}

2000 Munsell Soil Color Charts. New Windsor, New York: Munsell Color Company.

Munsey, C.

1970 The Illustrated Guide to Collecting Bottles. New York, New York: Hawthorne Books, Inc.

National Park Service (NPS)

1997 "How to Apply the National Register Criteria for Evaluation." National Register Bulletin.

Washington, D.C.: U.S. Depatrment of the Interior NPS. 1-54.

National Park Service

2002 "National Register Publications." National Register Bulletin: How to Apply the National

Register Criteria for Evaluation. Accessed 2018.

https://www.nps.gov/nr/publications/bulletins/nrb15/nrb15_2.htm.

Stambaugh, J. Lee, and Lilian J. Stambaugh

1958 "William Nelson Bush and Family." In A History of Collin County, Texas, 153-154. University of North Texas.

Stelle, L. J.

2011 An Archaeological Guide to Historic Artifacts of the Upper Sangamon Basin Central Illinois, U.S.A. Champaign, Illinois Parkland College. 24 2019. Accessed March 24, 3.

http://virtual.parkland.edu/lstelle1/len/archguide/documents/arcguide.htm.

Texas General Land Office

n.d. A Guide to the Peters Colony Records, 1841-1859. Accessed March 16, 2019.

https://legacy.lib.utexas.edu/taro/txglo/00049/glo-00049.html.

Texas Historical Commission

n.d. "Texas Archeological and Historic Sites Atlas." Austin, Texas. Accessed February 25, 2019.

https:atlas.thc.state.tx.us.

THC \& TARL

2019 Texas Archeological Sites Atlas. Accessed 2019. https://atlas.thc.state.tx.us/.

The Dallas Morning News

2013 "Obituary of George Pierce Cullum." The Dallas Morning News.

1971 "Obituary of Roy Clifford Ledbetter." The Dallas Morning News.

United States Geological Survey (USGS)

2019 EarthExplorer. Accessed February 22, 2019. https://earthexplorer.usgs.gov/.

Unknown

1880 Biographical Encyclopedia of Texas. New York: Southern Publishing Company. 
USDC

2019 U.S. Census. Accessed October 24, 2019. https://www.census.gov.

USGS

2019 Historical Topographic Map Explorer. Accessed February 22, 2019.

https://historicalmaps.arcgis.com/usgs/. 
APPENDIX A

Project Maps 


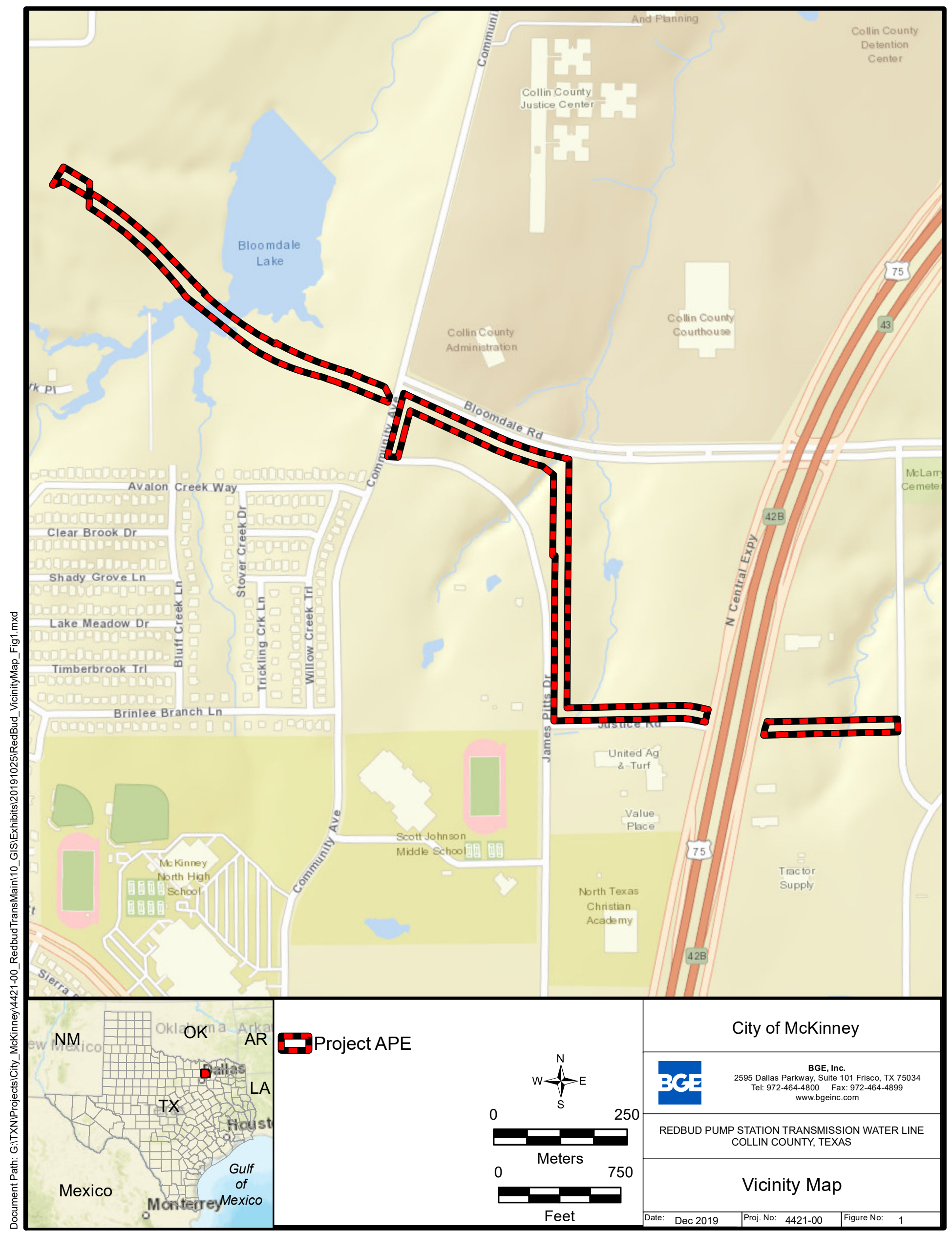

Service Layer Credits: Sources: Esri, HERE, Garmin, USGS, Intermap, INCREMENT P, NRCan, Esri Japan, METI, Esri China (Hong Kong), Esri Korea, Esri (Thailand), NGCC, ๑ OpenStreetMap contributors, and the GIS User
Community 


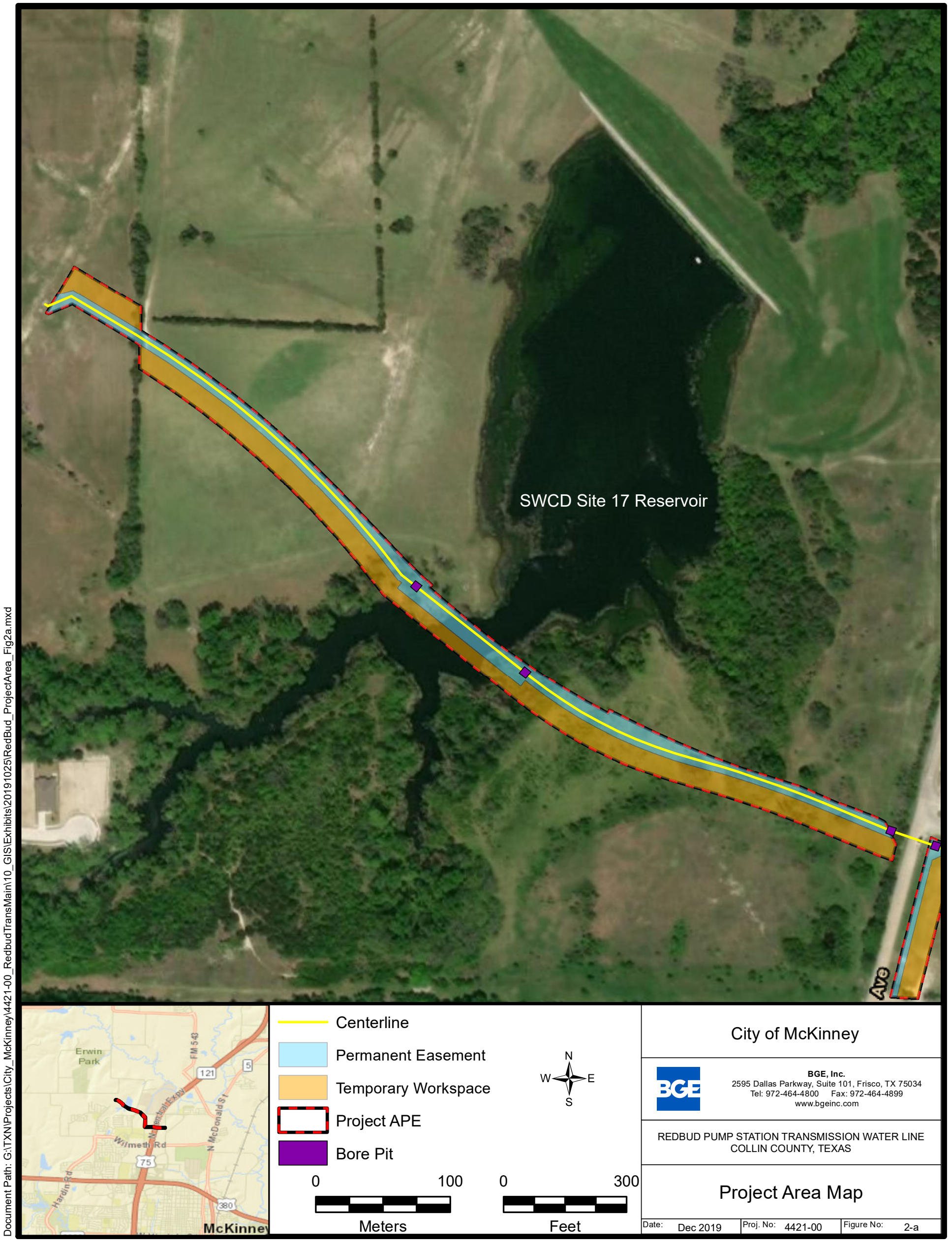

Service Layer Credits: Esri, HERE, Garmin, (c) OpenStreetMap contributors

Sources: Esri, HERE, Garmin, USGS, Intermap, INCREMENT P, NRCan, Esri Japan, METI, Esri China (Hong Kong), Esri Korea, Esri (Thailand), NGCC, ๑ OpenStreetMap contributors, and the GIS User Community Source: Esri, DigitalGlobe, GeoEye, Earthstar Geographics, CNES/Airbus DS, USDA, USGS, AeroGRID, IGN, and the GIS User Community 


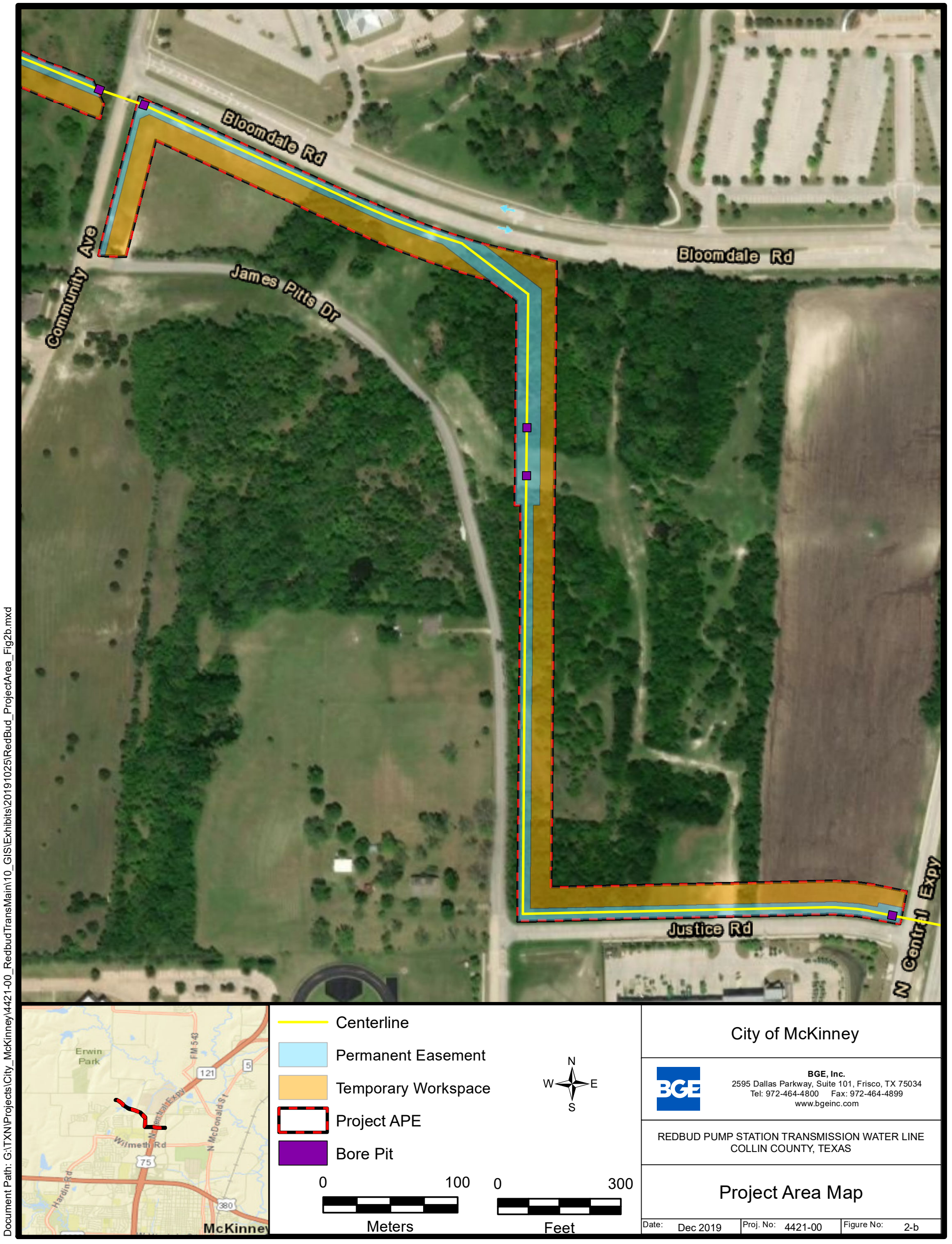

Service Layer Credits: Esri, HERE, Garmin, (c) OpenStreetMap contributors

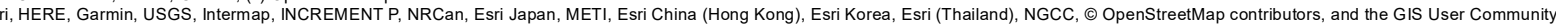
Source: Esri, DigitalGlobe, GeoEye, Earthstar Geographics, CNES/Airbus DS, USDA, USGS, AeroGRID, IGN, and the GIS User Community 


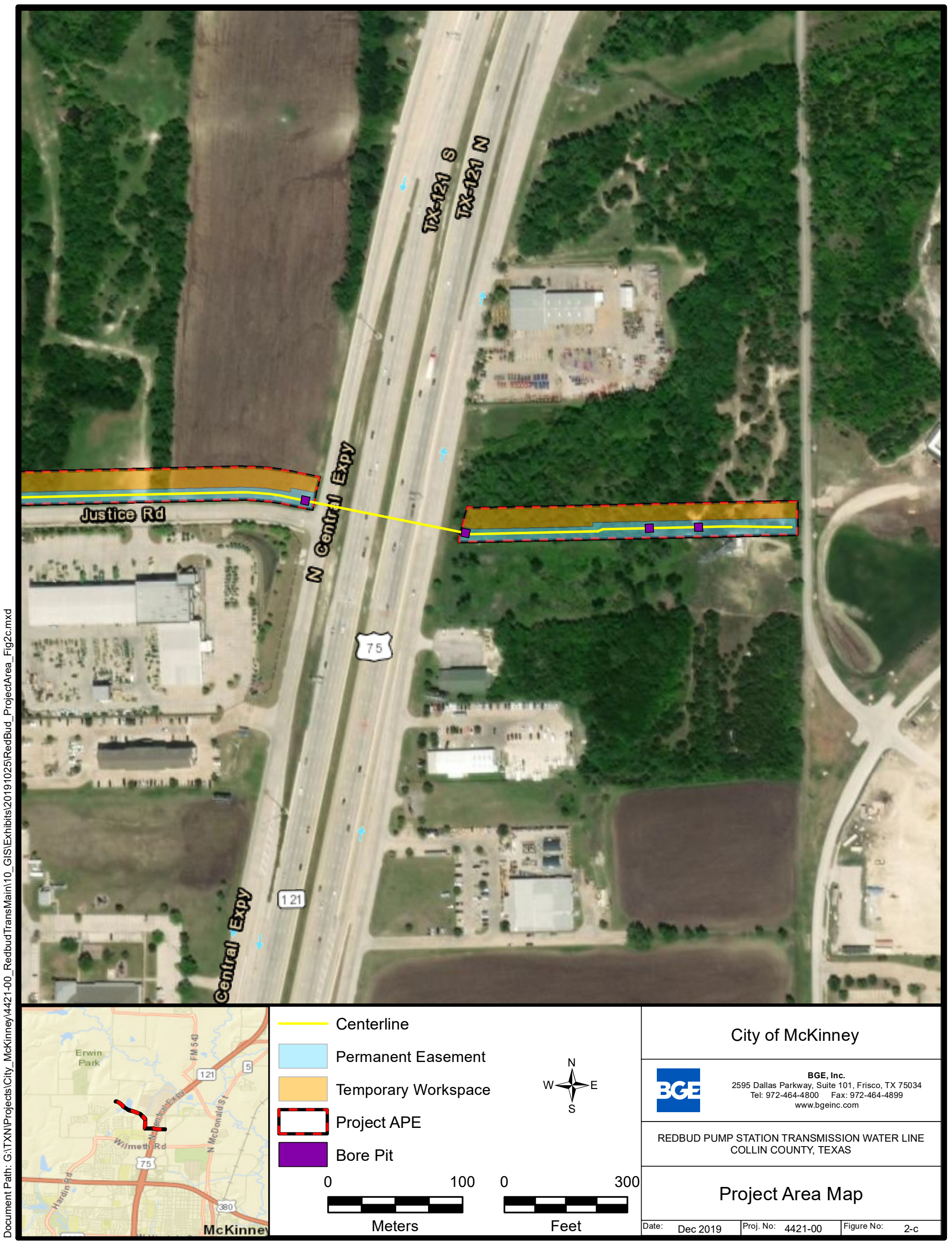

Service Layer Credits: Esri, HERE, Garmin, (c) OpenStreetMap contributors

Sources: Esri, HERE, Garmin, USGS, Intermap, INCREMENT P, NRCan, Esri Japan, METI, Esri China (Hong Kong), Esri Korea, Esri (Thailand), NGCC, ๑ OpenStreetMap contributors, and the GIS User Community Source: Esri, DigitalGlobe, GeoEye, Earthstar Geographics, CNES/Airbus DS, USDA, USGS, AeroGRID, IGN, and the GIS User Community 


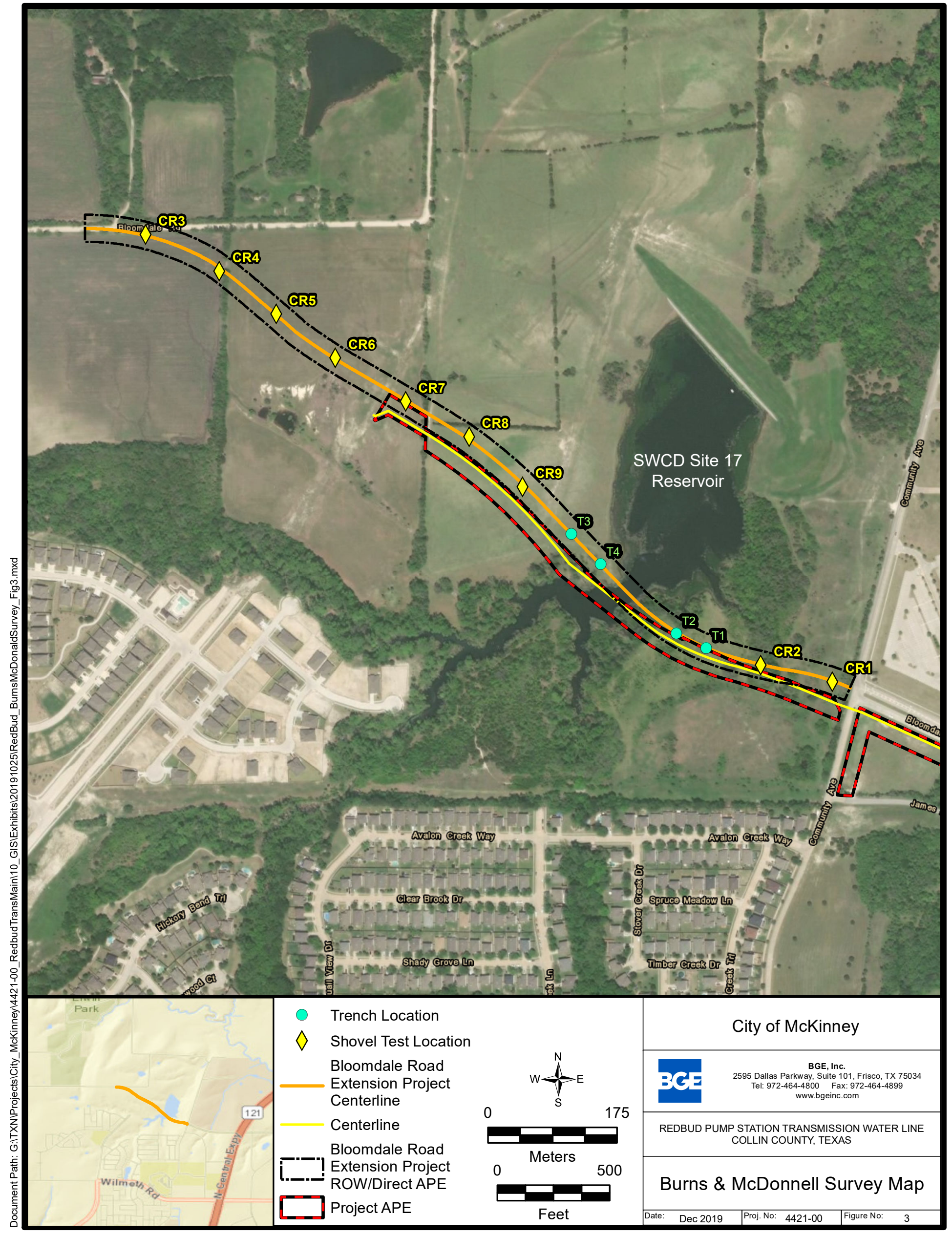

Service Layer Credits: Esri, HERE, Garmin, $\odot$ OpenStreetMap contributors

Sources: Esri, HERE, Garmin, USGS, Intermap, INCREMENT P, NRCan, Esri Japan, METI, Esri China (Hong Kong), Esri Korea, Esri (Thailand), NGCC, ๑ OpenStreetMap contributors, and the GIS User Community Source: Esri, DigitalGlobe, GeoEye, Earthstar Geographics, CNES/Airbus DS, USDA, USGS, AeroGRID, IGN, and the GIS User Community 


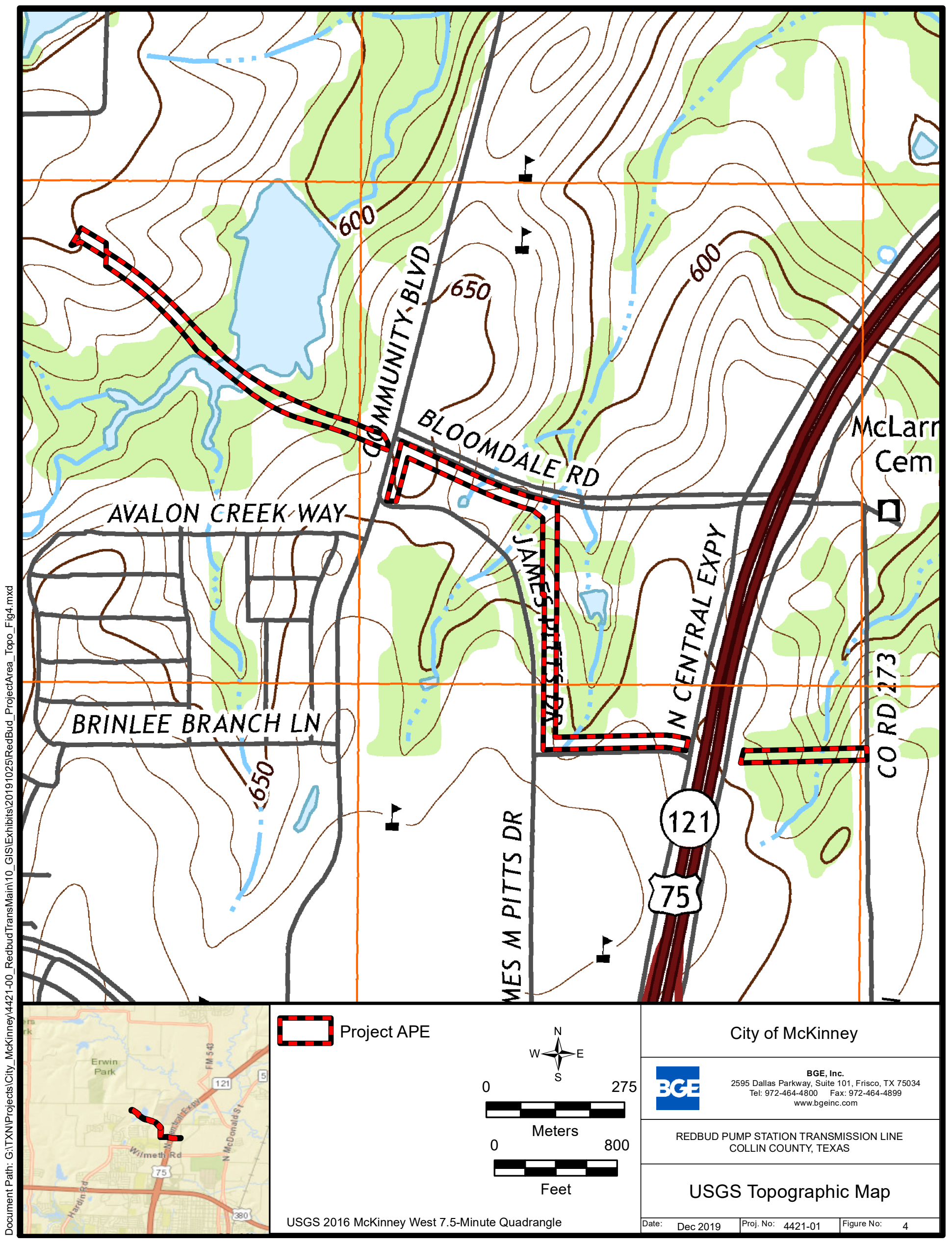




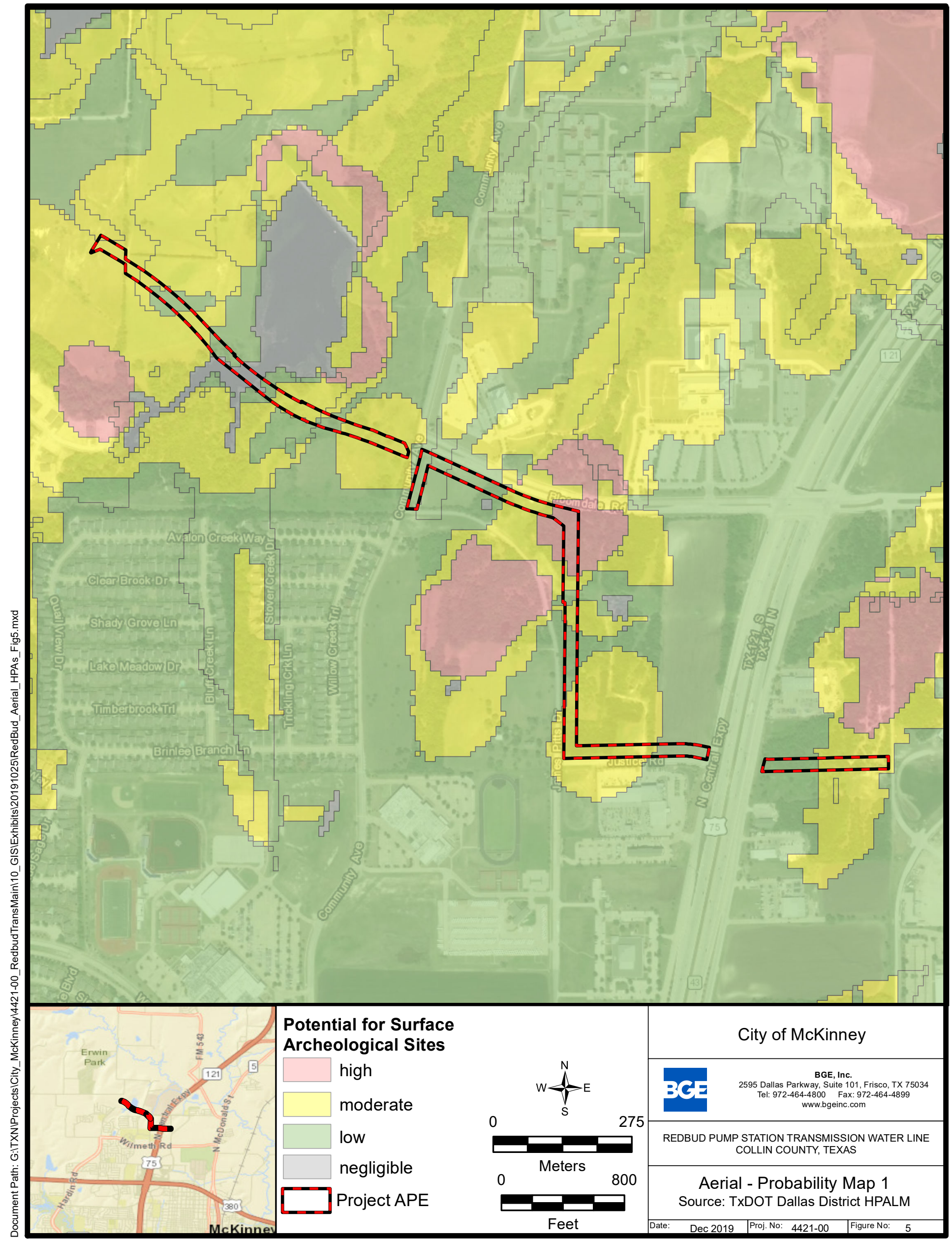

Service Layer Credits: Esri, HERE, Garmin, (c) OpenStreetMap contributors

Sources: Esri, HERE, Garmin, USGS, Intermap, INCREMENT P, NRCan, Esri Japan, METI, Esri China (Hong Kong), Esri Korea, Esri (Thailand), NGCC, ๑ OpenStreetMap contributors, and the GIS User Community Source: Esri, DigitalGlobe, GeoEye, Earthstar Geographics, CNES/Airbus DS, USDA, USGS, AeroGRID, IGN, and the GIS User Community 


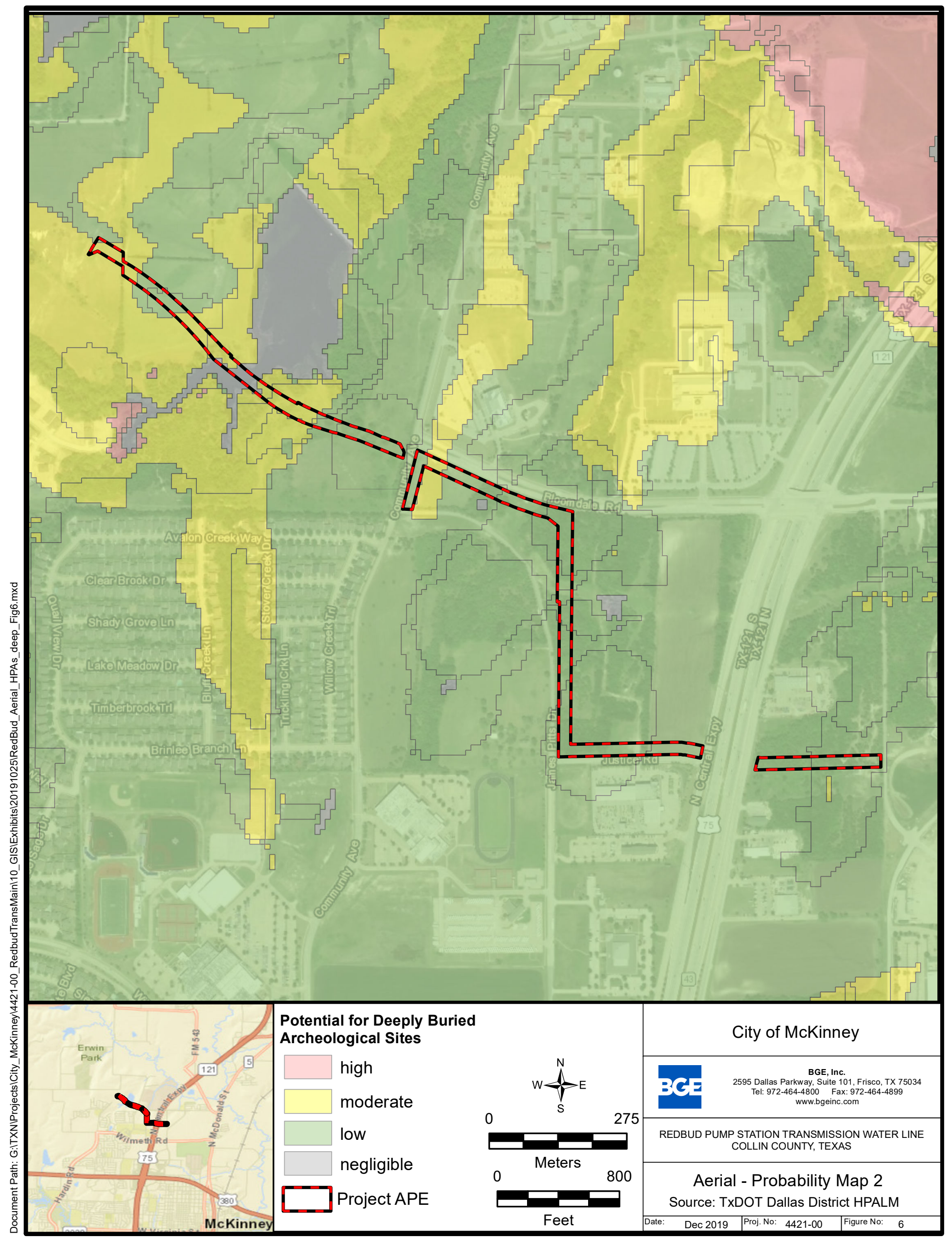

Service Layer Credits: Esri, HERE, Garmin, (c) OpenStreetMap contributors

Sources: Esri, HERE, Garmin, USGS, Intermap, INCREMENT P, NRCan, Esri Japan, METI, Esri China (Hong Kong), Esri Korea, Esri (Thailand), NGCC, ๑ OpenStreetMap contributors, and the GIS User Community

Source: Esri, DigitalGlobe, GeoEye, Earthstar Geographics, CNES/Airbus DS, USDA, USGS, AeroGRID, IGN, and the GIS User Community 


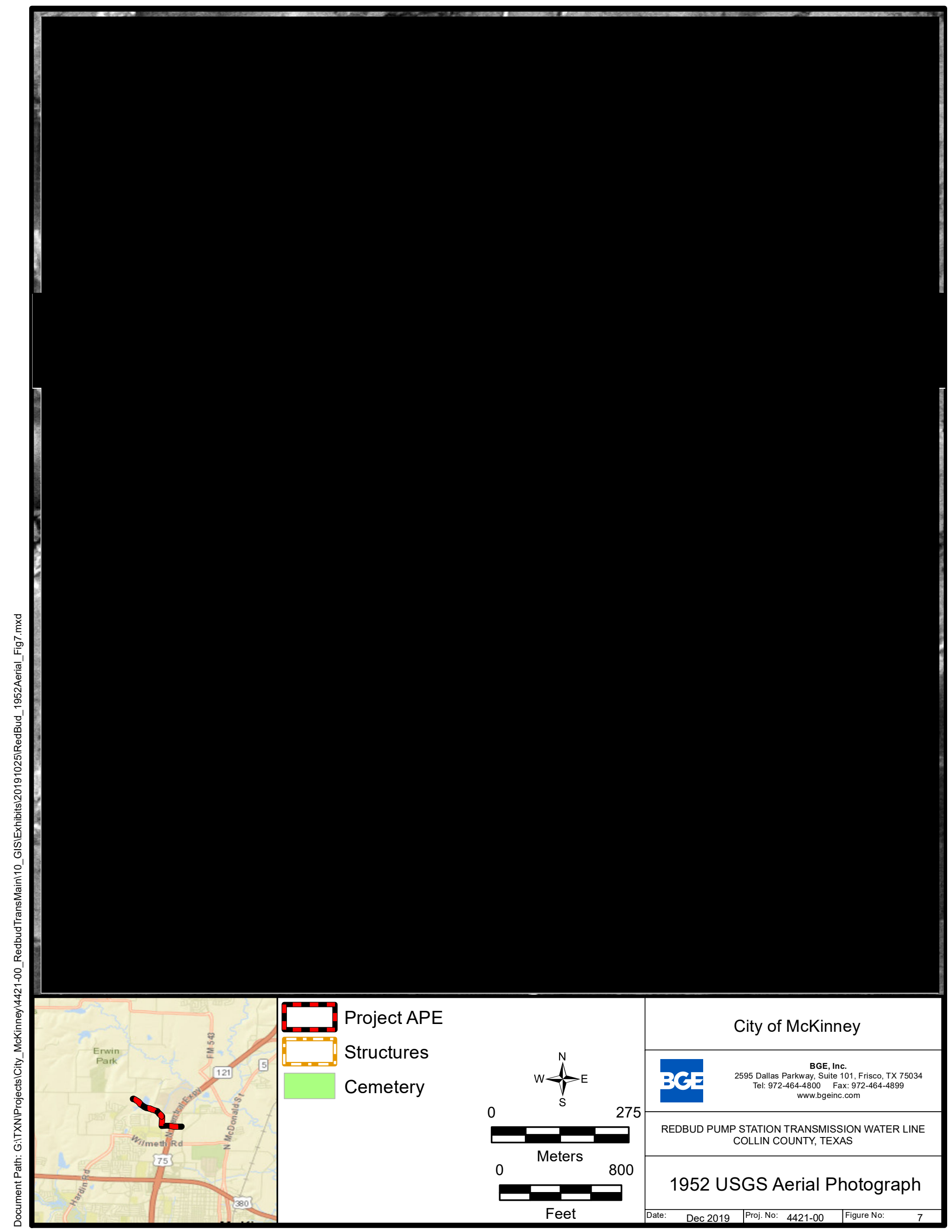

Service Layer Credits: Sources: Esri, HERE, Garmin, USGS, Intermap, INCREMENT P, NRCan, Esri Japan, METI, Esri China (Hong Kong), Esri Korea, Esri (Thailand), NGCC, ๑ OpenStreetMap contributors, and the GIS User Community 


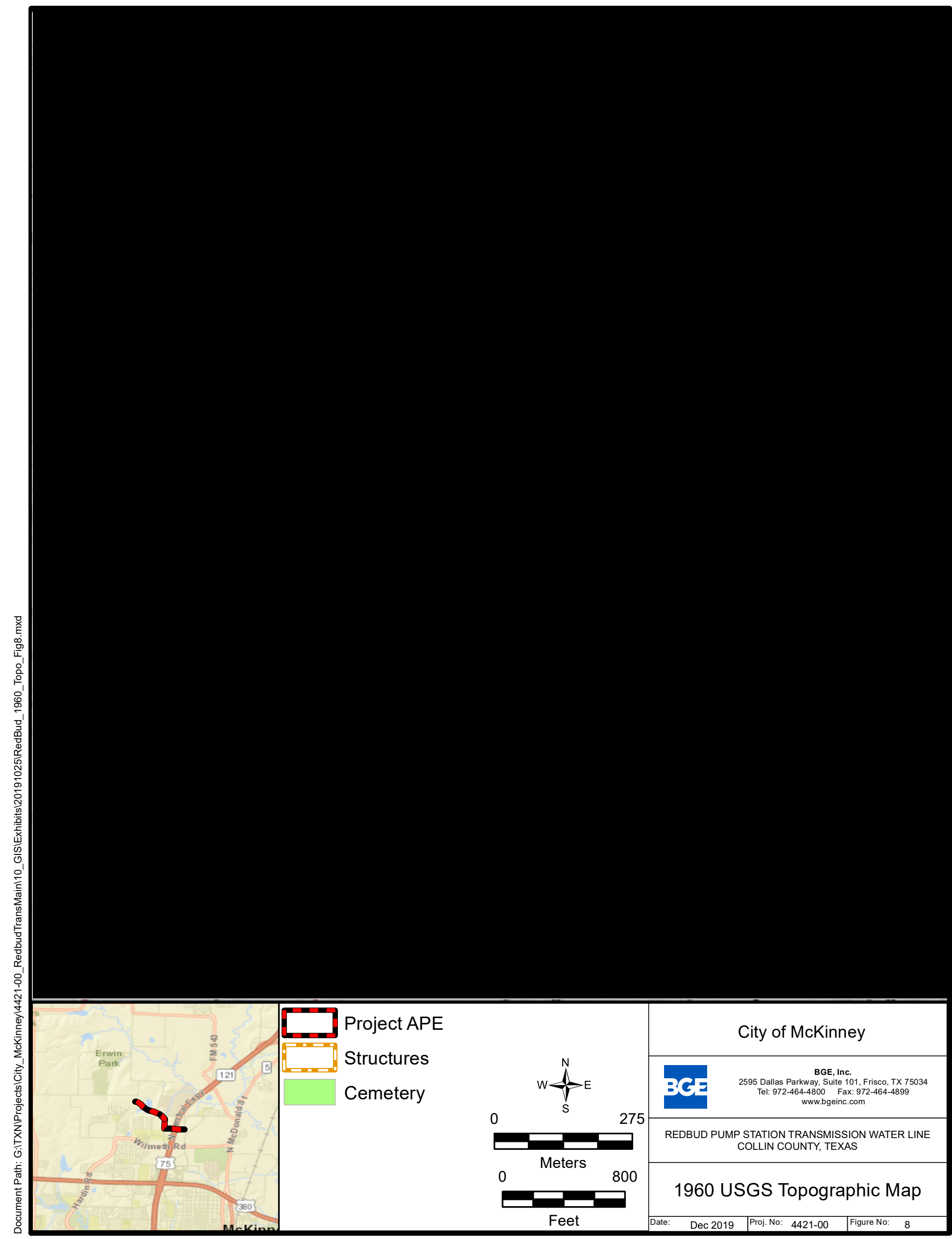

Service Layer Credits: Sources: Esri, HERE, Garmin, USGS, Intermap, INCREMENT P, NRCan, Esri Japan, METI, Esri China (Hong Kong), Esri Korea, Esri (Thailand), NGCC, ๑ OpenStreetMap contributors, and the GIS User 


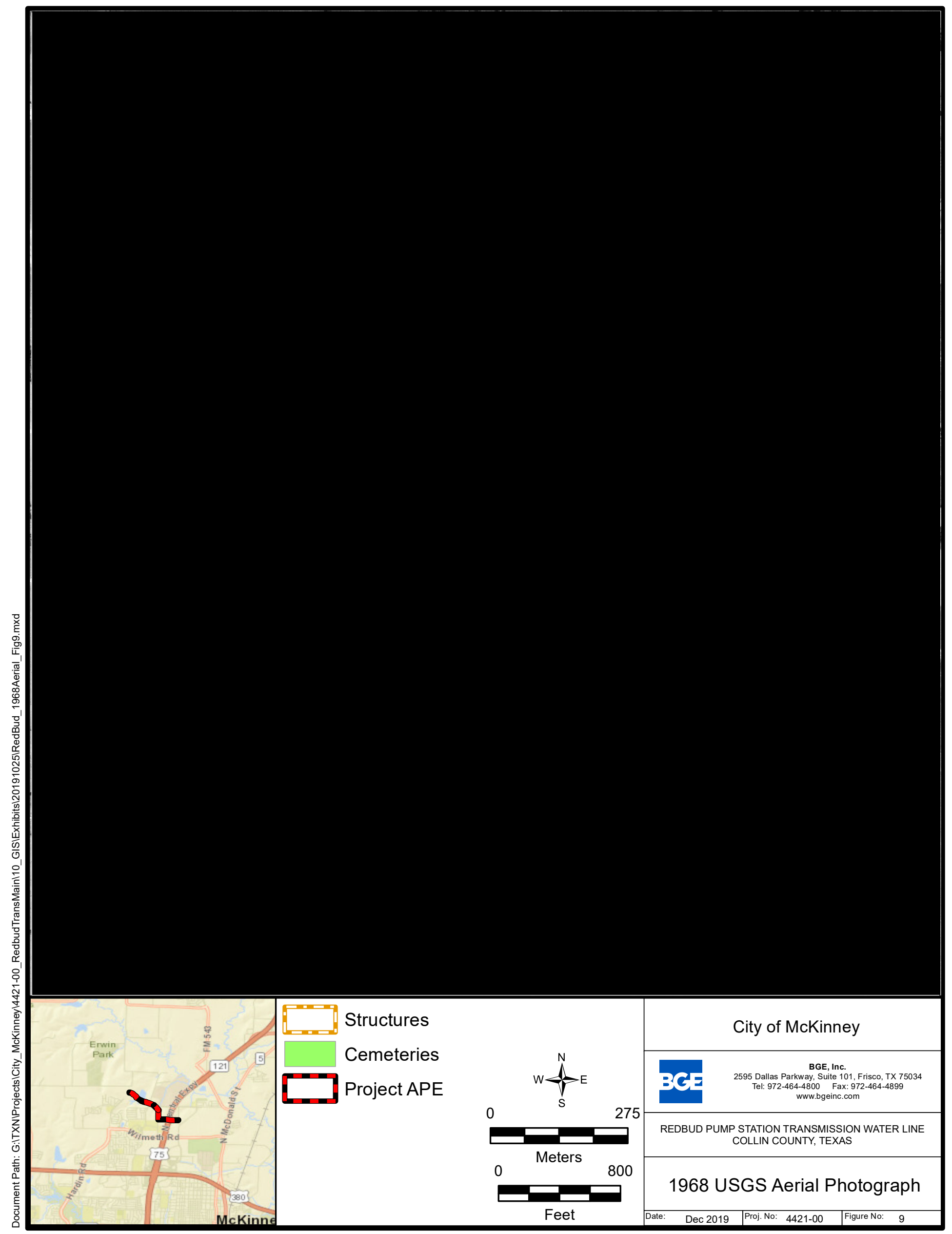

Service Layer Credits: Sources: Esri, HERE, Garmin, USGS, Intermap, INCREMENT P, NRCan, Esri Japan, METI, Esri China (Hong Kong), Esri Korea, Esri (Thailand), NGCC, ๑ OpenStreetMap contributors, and the GIS User 


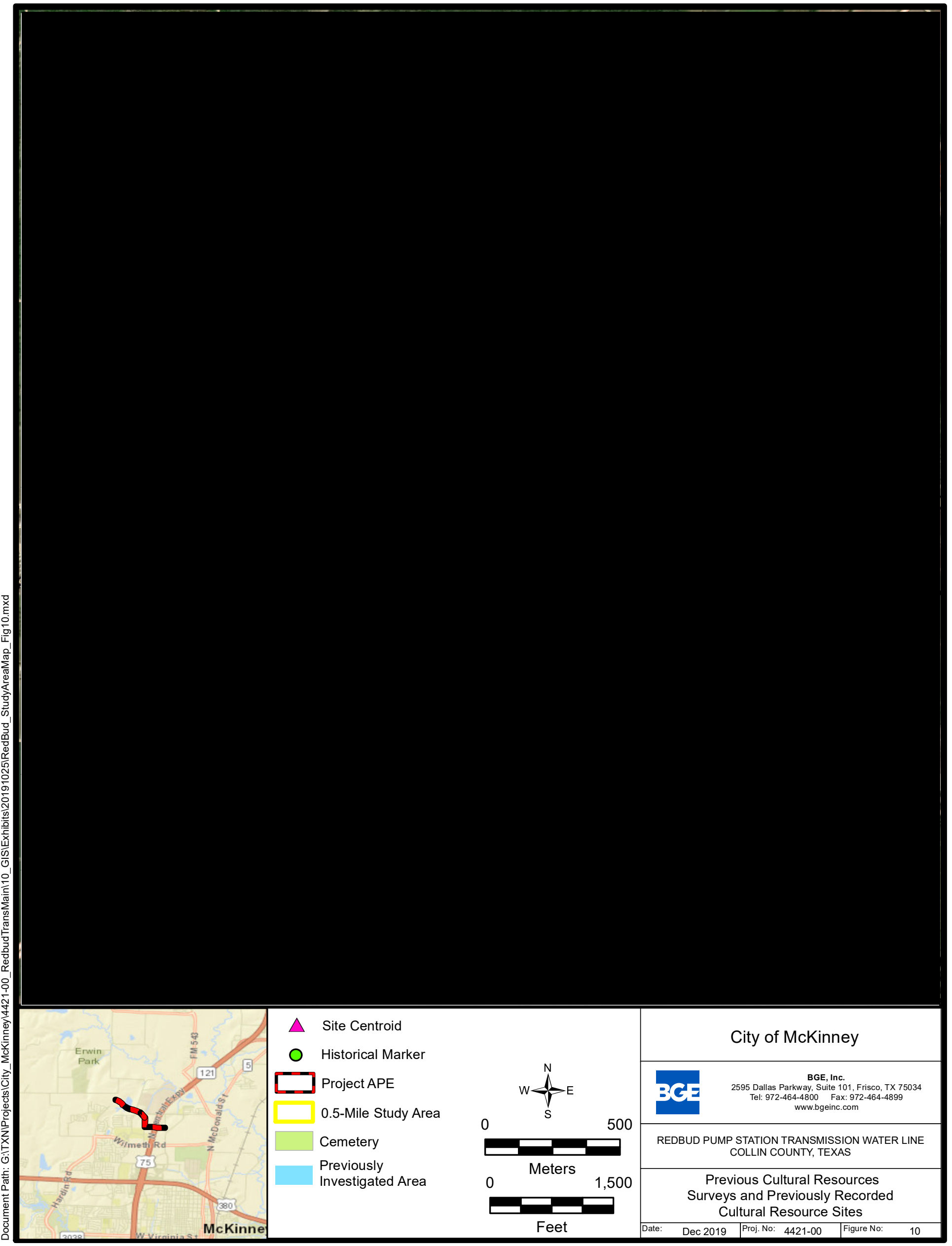

Service Layer Credits: Esri, HERE, Garmin, ๑ OpenStreetMap contributors

Sources: Esri, HERE, Garmin, USGS, Intermap, INCREMENT P, NRCan, Esri Japan, METI, Esri China (Hong Kong), Esri Korea, Esri (Thailand), NGCC, ๑ OpenStreetMap contributors, and the GIS User Community Source: Esri, DigitalGlobe, GeoEye, Earthstar Geographics, CNES/Airbus DS, USDA, USGS, AeroGRID, IGN, and the GIS User Community 


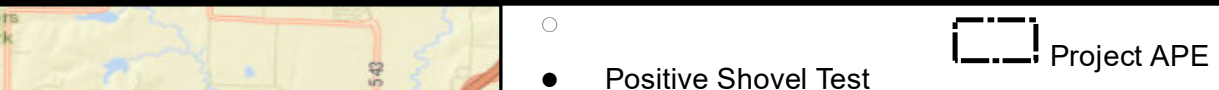

- Positive Shovel Test

$\oplus$ Surface Inspection

- Trench Location 2017 B\&M Project Centerline

Project Centerline

Bore Pit

Project APE

$$
\text { P }
$$

0

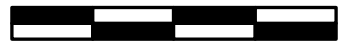

Meters

0

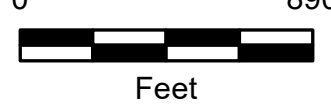

City of McKinney

BGE, Inc.

BGE, Inc.
2595 Dallas Parkway, Suite 101, Frisco, TX 75034 Tel: 972-464-4800 Fax: 972-464-4899

$$
\text { www.bgeinc.com }
$$

REDBUD PUMP STATION TRANSMISSION WATER LINE COLLIN COUNTY, TEXAS

\section{Field Investigation Results Map}

\begin{tabular}{l|l|l} 
Dec 2019 & Proj. No: $4421-00$ & Figure No:
\end{tabular} 


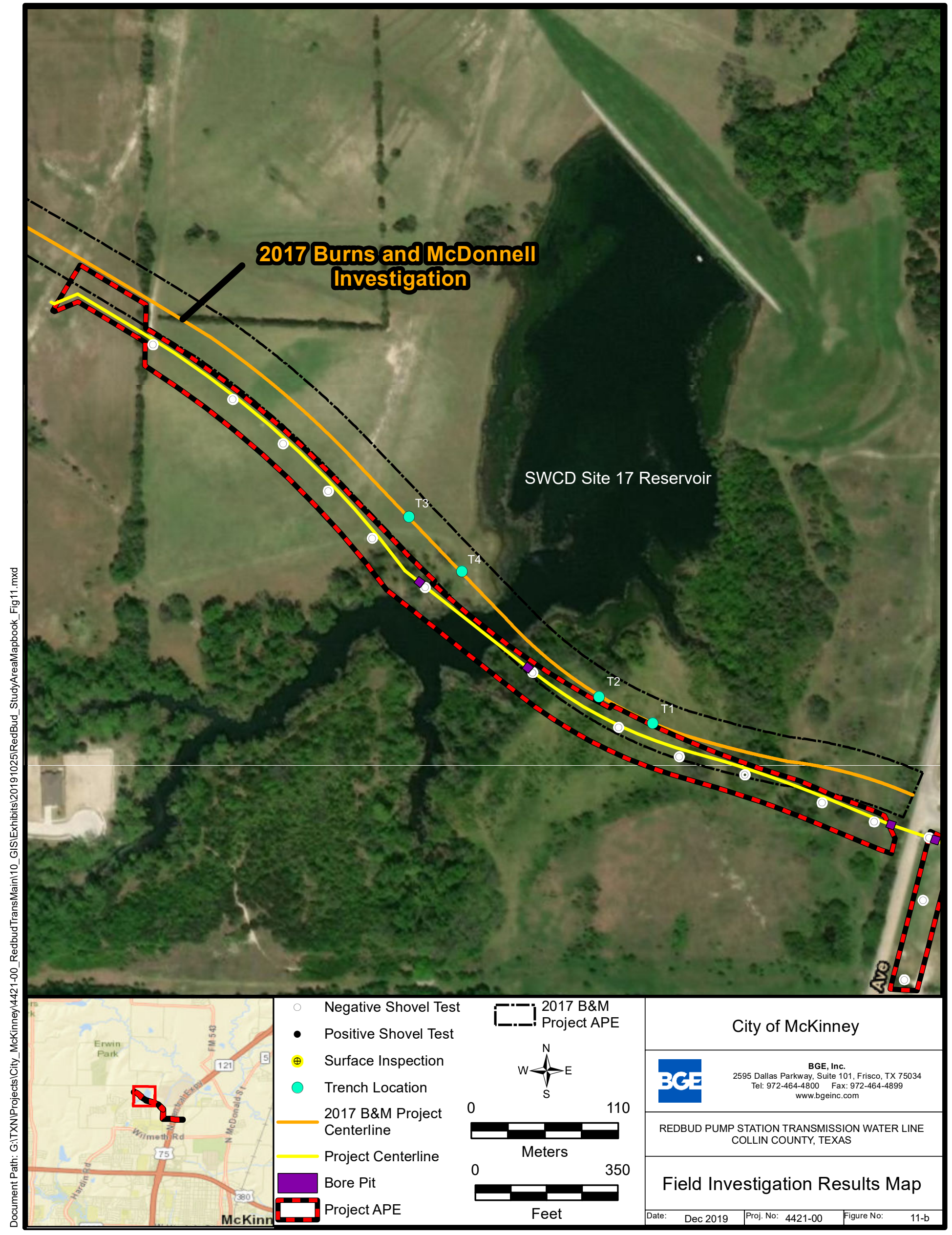


- Positive Shovel Test

$\oplus \quad$ Surface Inspection

Trench Location 2017 B\&M Project Centerline

Project Centerline

Bore Pit

Project APE
I-_ Project APE

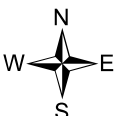

0 110

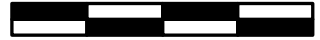

Meters

0

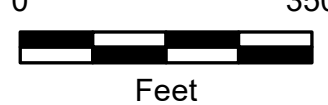

City of McKinney

BGE, Inc.
2595 Dallas Parkway, Suite 101, Frisco, TX 75034 Tel: $972-464-4800 \quad$ Fax: $972-464-489$

$$
\text { www.bgeinc.com }
$$

REDBUD PUMP STATION TRANSMISSION WATER LINE COLLIN COUNTY, TEXAS

Service Layer Credits: Esri, HERE, Garmin, $\odot$ OpenStreetMap contributors

Sources: Esri, HERE, Garmin, USGS, Intermap, INCREMENT P, NRCan, Esri Japan, METI, Esri China (Hong Kong), Esri Korea, Esri (Thailand), NGCC, ๑ OpenStreetMap contributors, and the GIS User Community

Source: Esri, DigitalGlobe, GeoEye, Earthstar Geographics, CNES/Airbus DS, USDA, USGS, AeroGRID, IGN, and the GIS User Community 


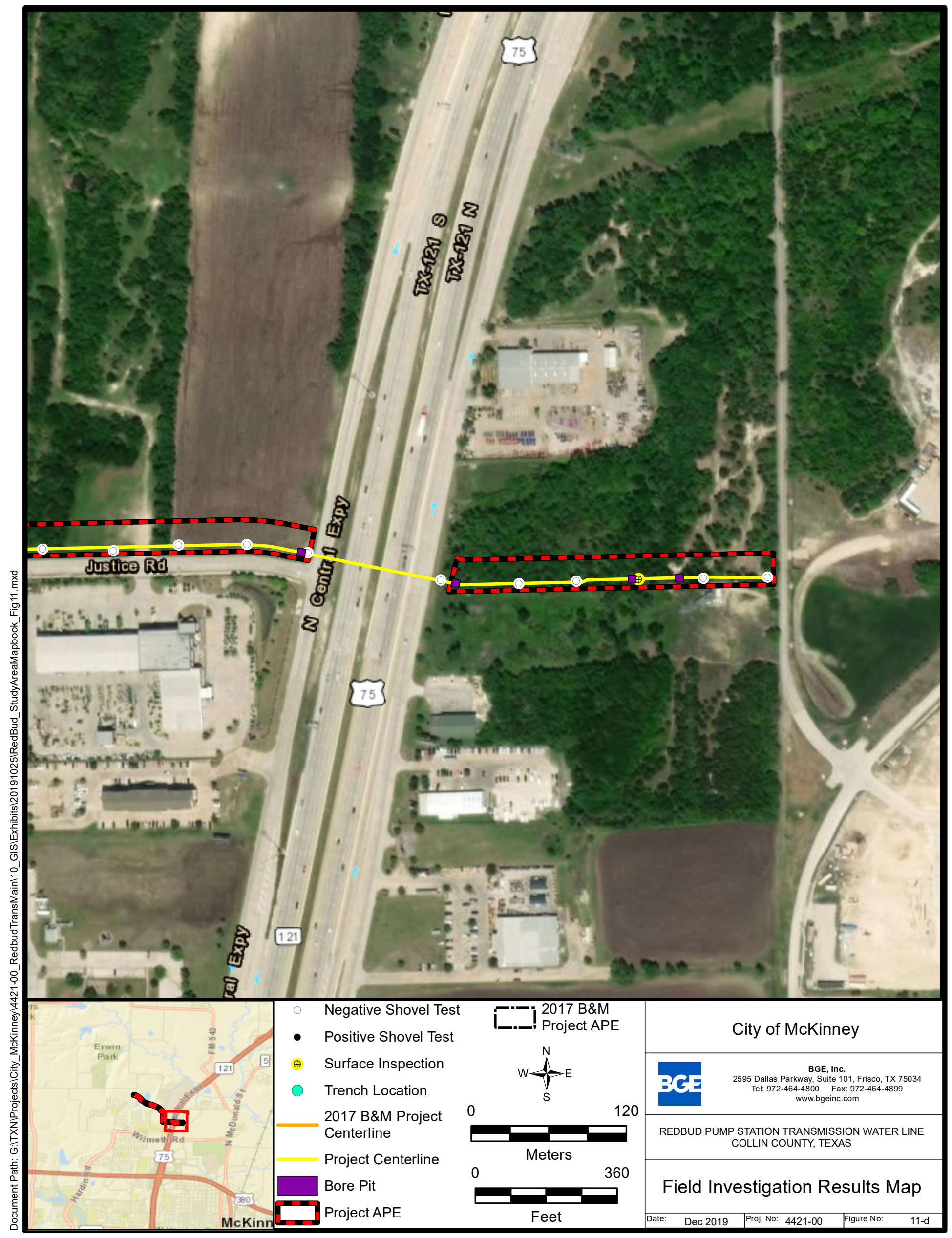

Service Layer Credits: Esri, HERE, Garmin, ๑ OpenStreetMap contributors

Sources: Esri, HERE, Garmin, USGS, Intermap, INCREMENT P, NRCan, Esri Japan, METI, Esri China (Hong Kong), Esri Korea, Esri (Thailand), NGCC, ๑ OpenStreetMap contributors, and the GIS User Community 


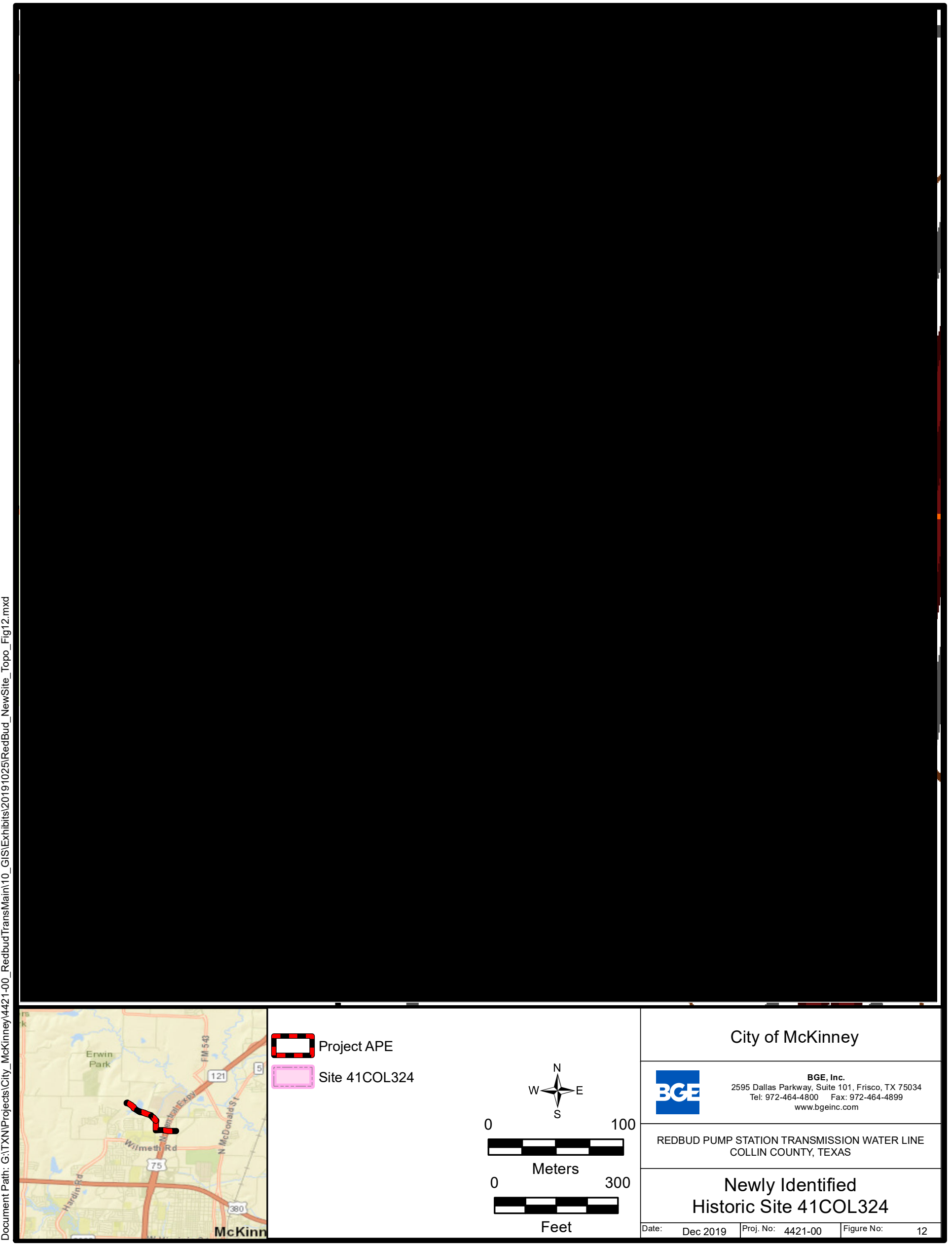

Service Layer Credits: Sources: Esri, HERE, Garmin, USGS, Intermap, INCREMENT P, NRCan, Esri Japan, METI, Esri China (Hong Kong), Esri Korea, Esri (Thailand), NGCC, ๑ OpenStreetMap contributors, and the GIS User 


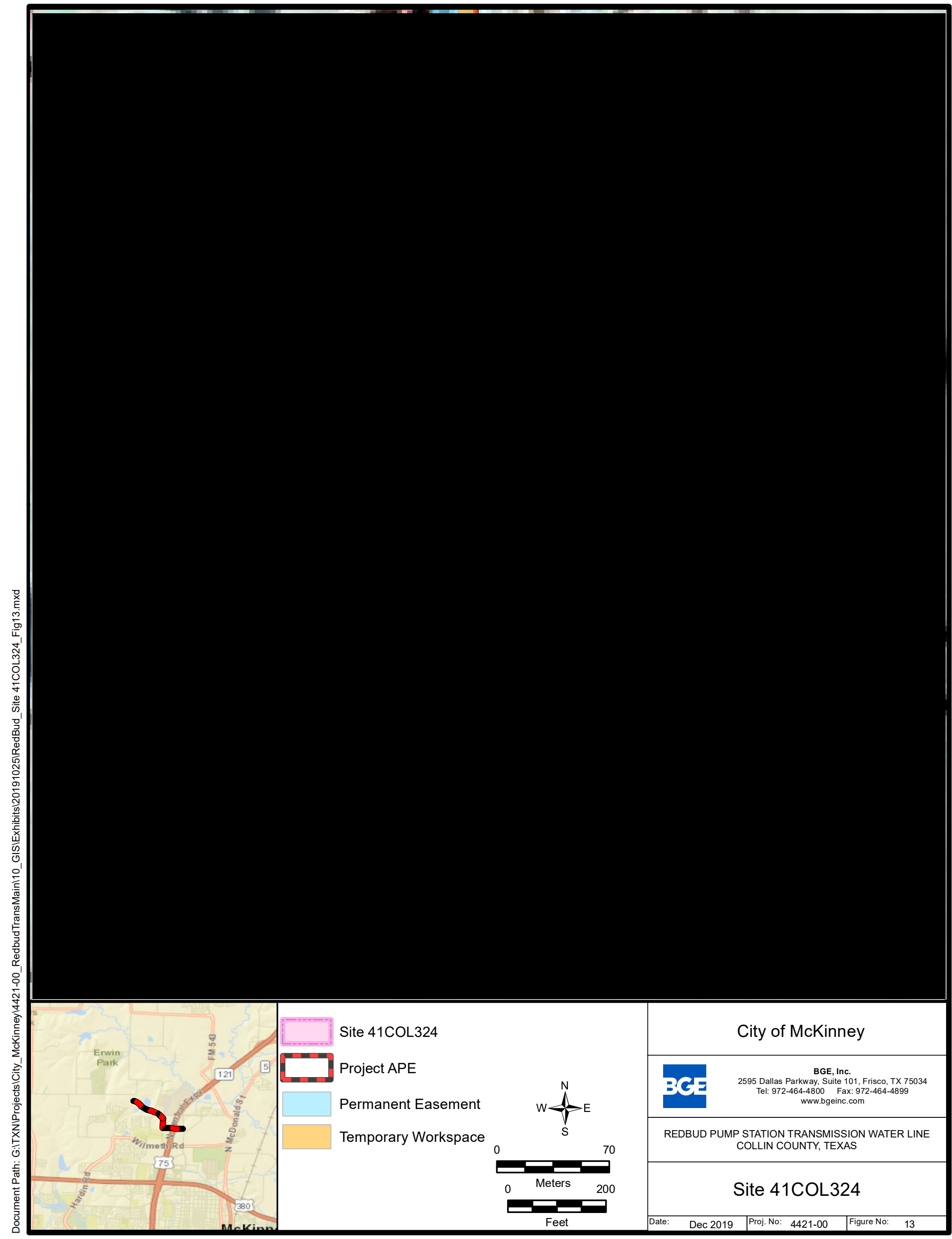

Service Layer Credits: Sources: Esri, HERE, Garmin, USGS, Intermap, INCREMENT P, NRCan, Esri Japan, METI, Esri China (Hong Kong), Esri Korea, Esri (Thailand), NGCC, ๑ OpenStreetMap contributors, and the GIS User Community 


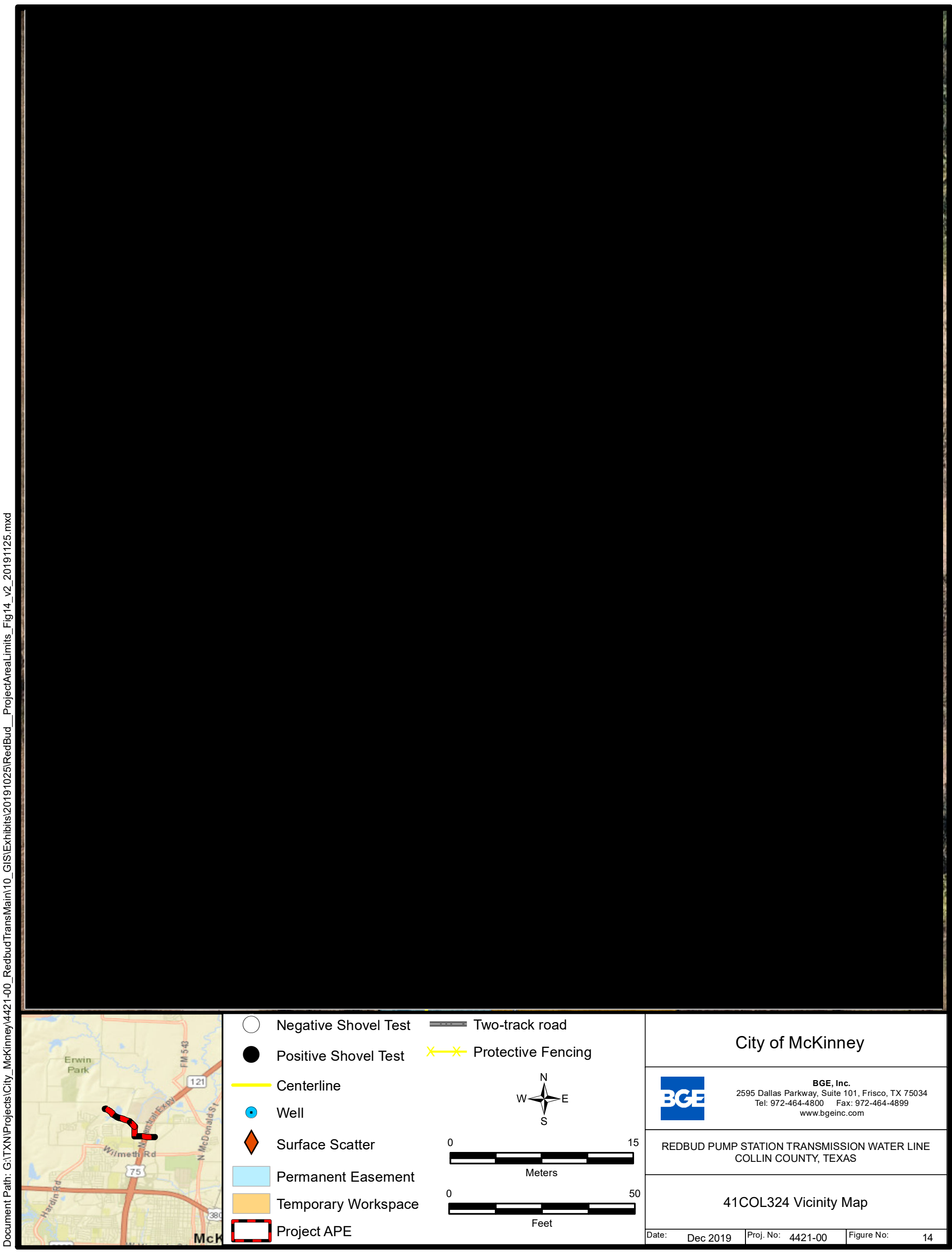


APPENDIX B

Project Photographs 


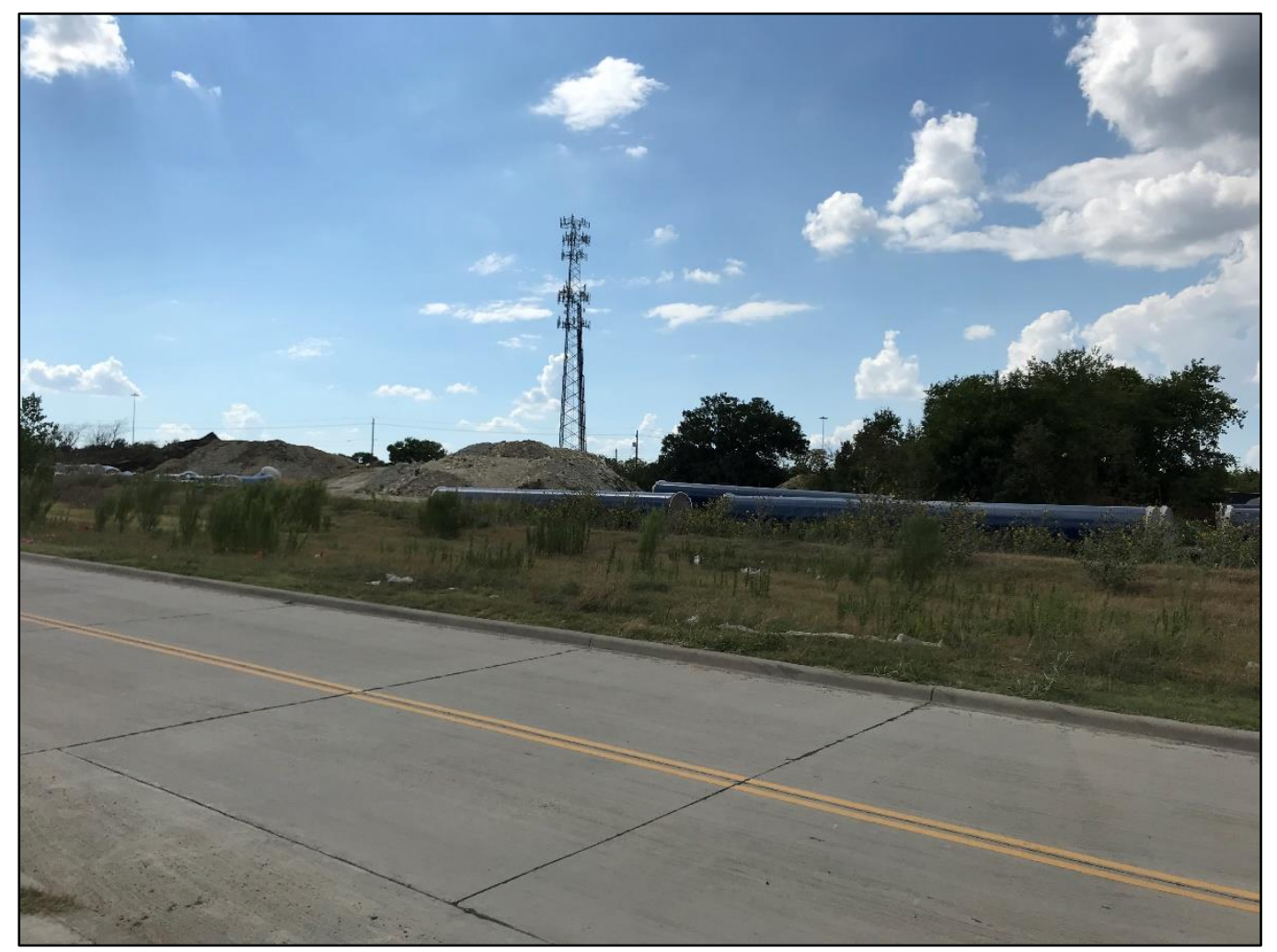

Figure 1. Location of proposed Redbud Pump Station west of Redbud Boulevard. Facing southwest.

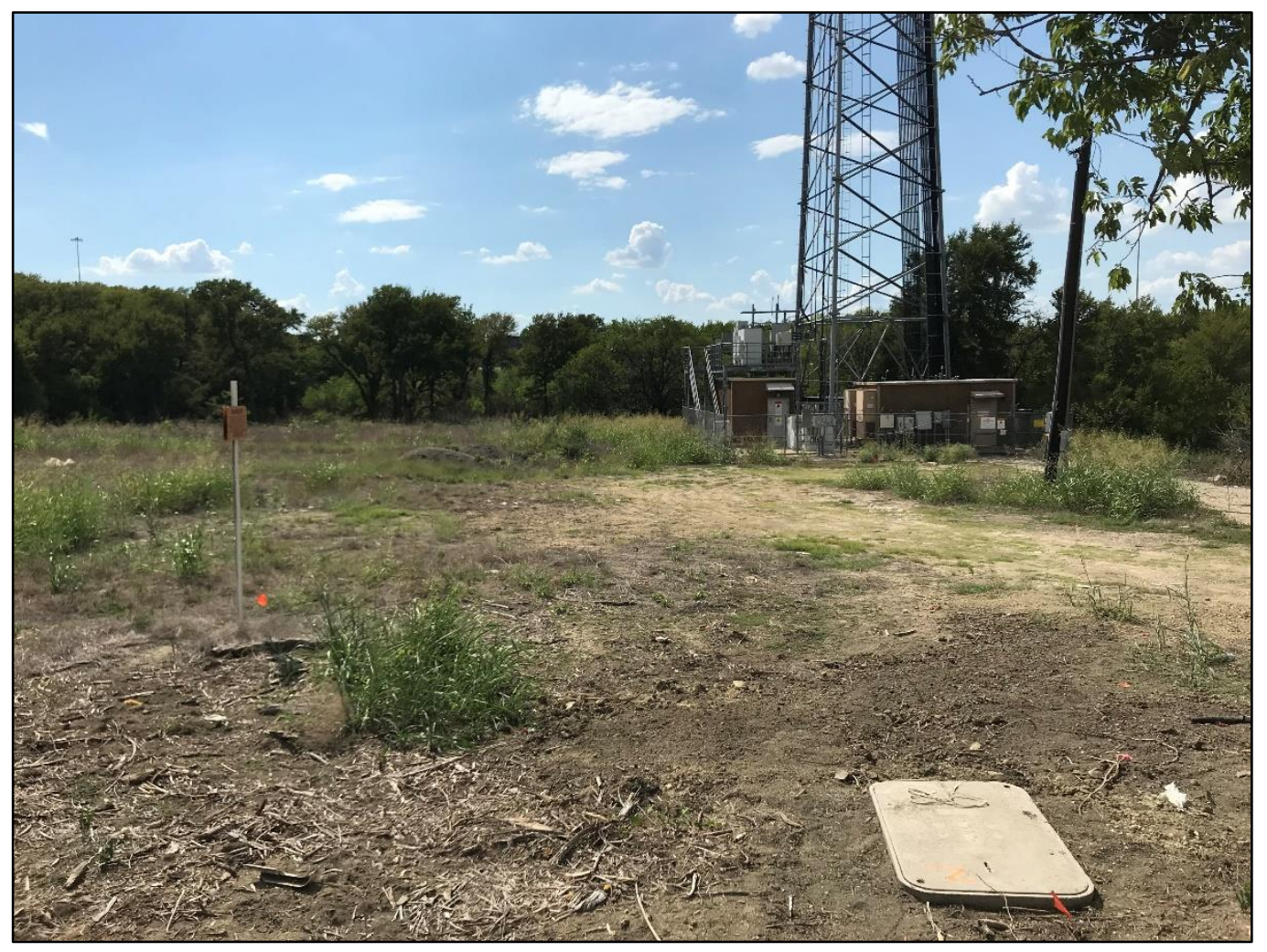

Figure 2. Transmission line easement west of Redbud Boulevard/CR 273 . Facing west. 


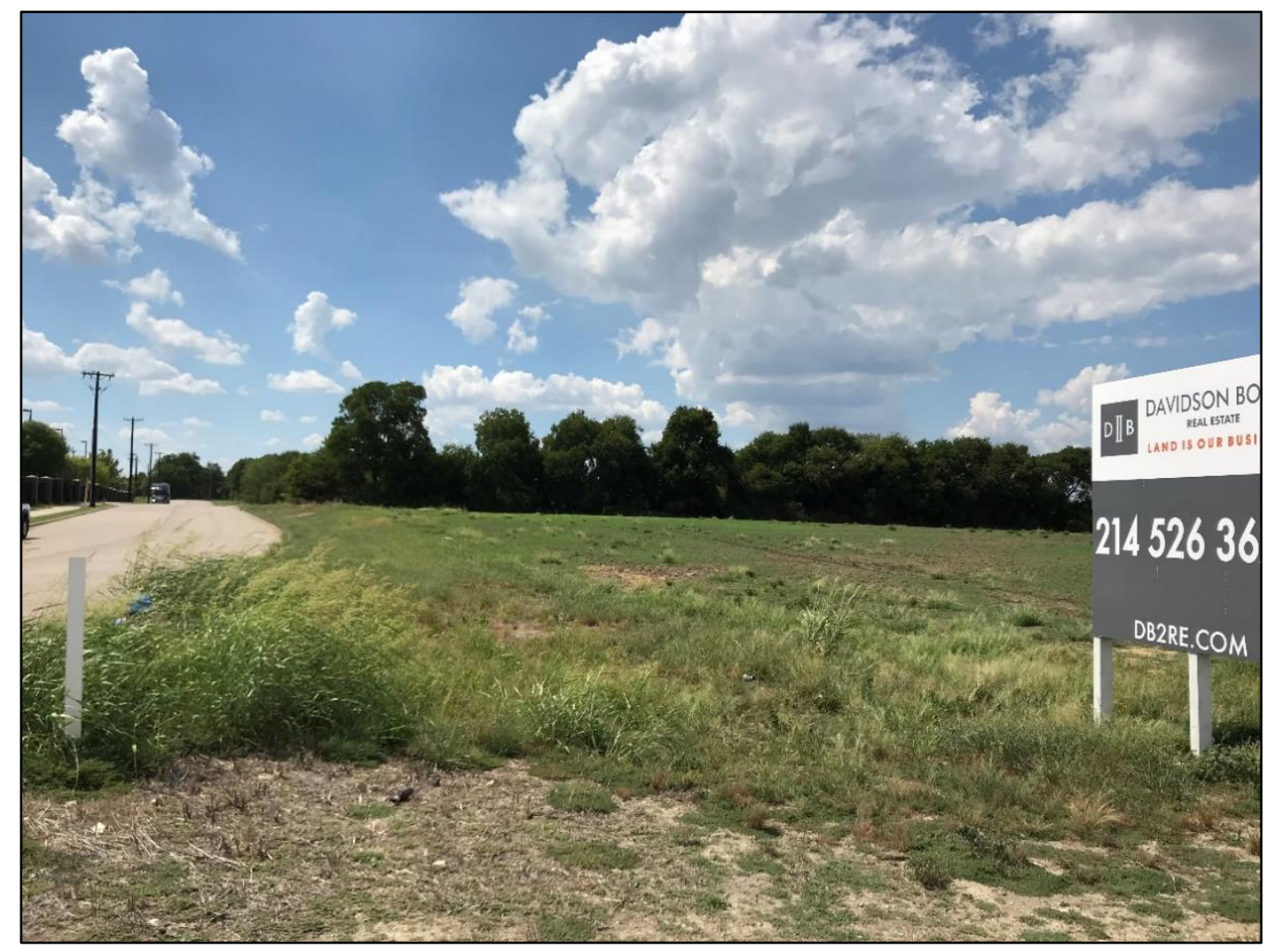

Figure 3. Transmission line easement west of N. Central Expressway and I-75. Facing west.

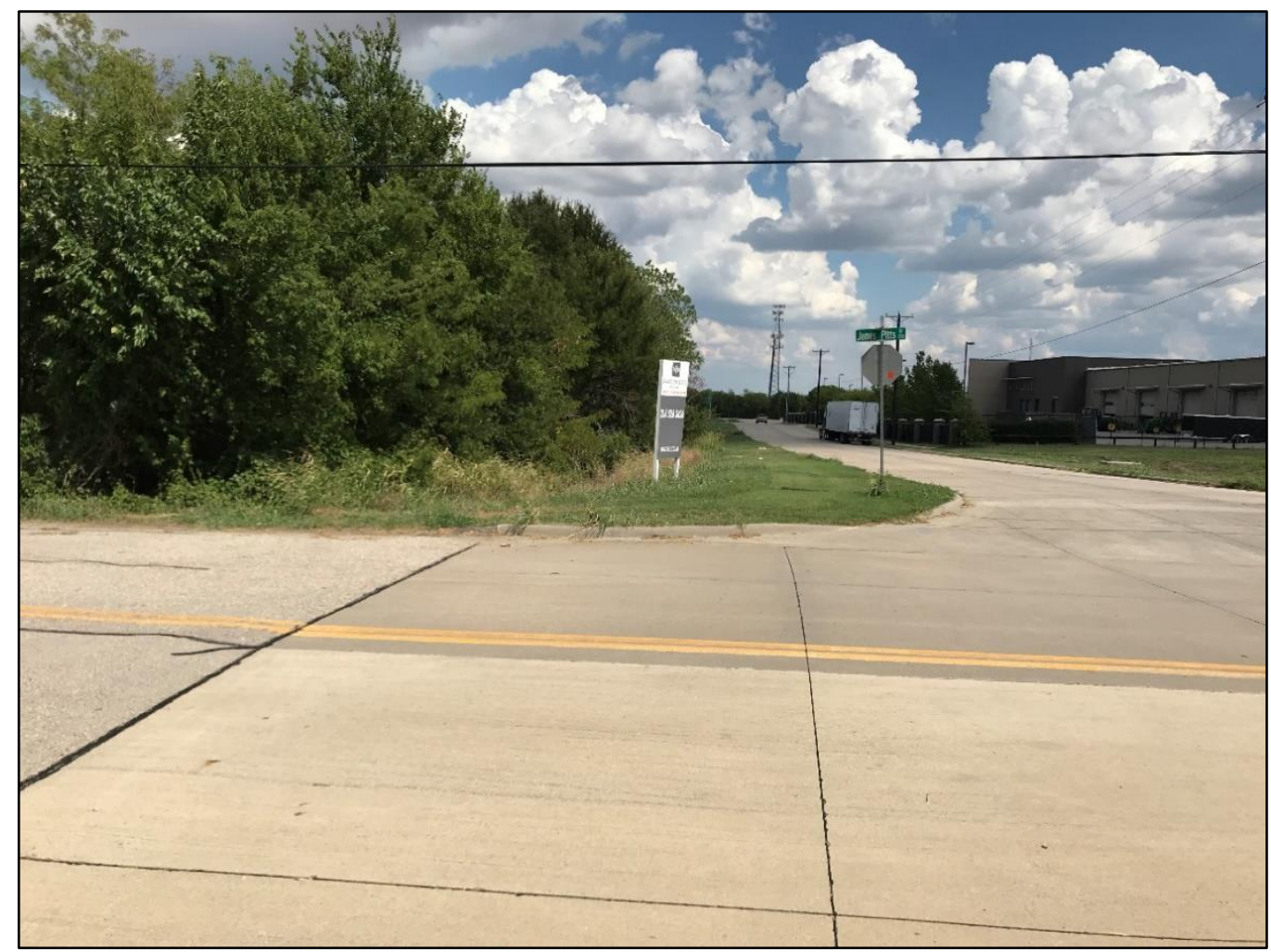

Figure 4. Transmission line easement north of Justice Road, east of James Pitts Drive, west of N. Central Expressway and I-75. Facing east. 


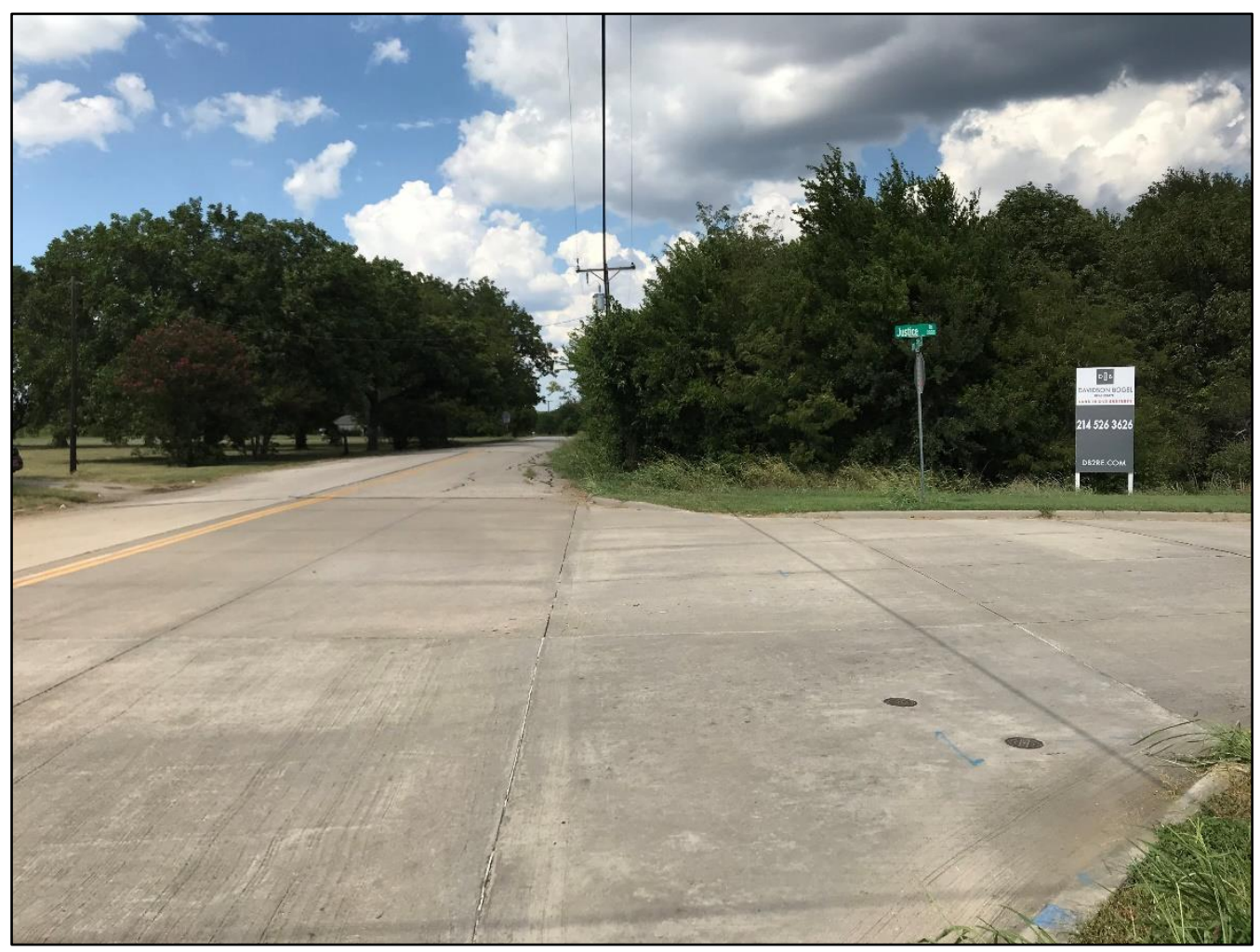

Figure 5. Transmission line easement at intersection of James Pitts Drive and Justice Road. Facing south.

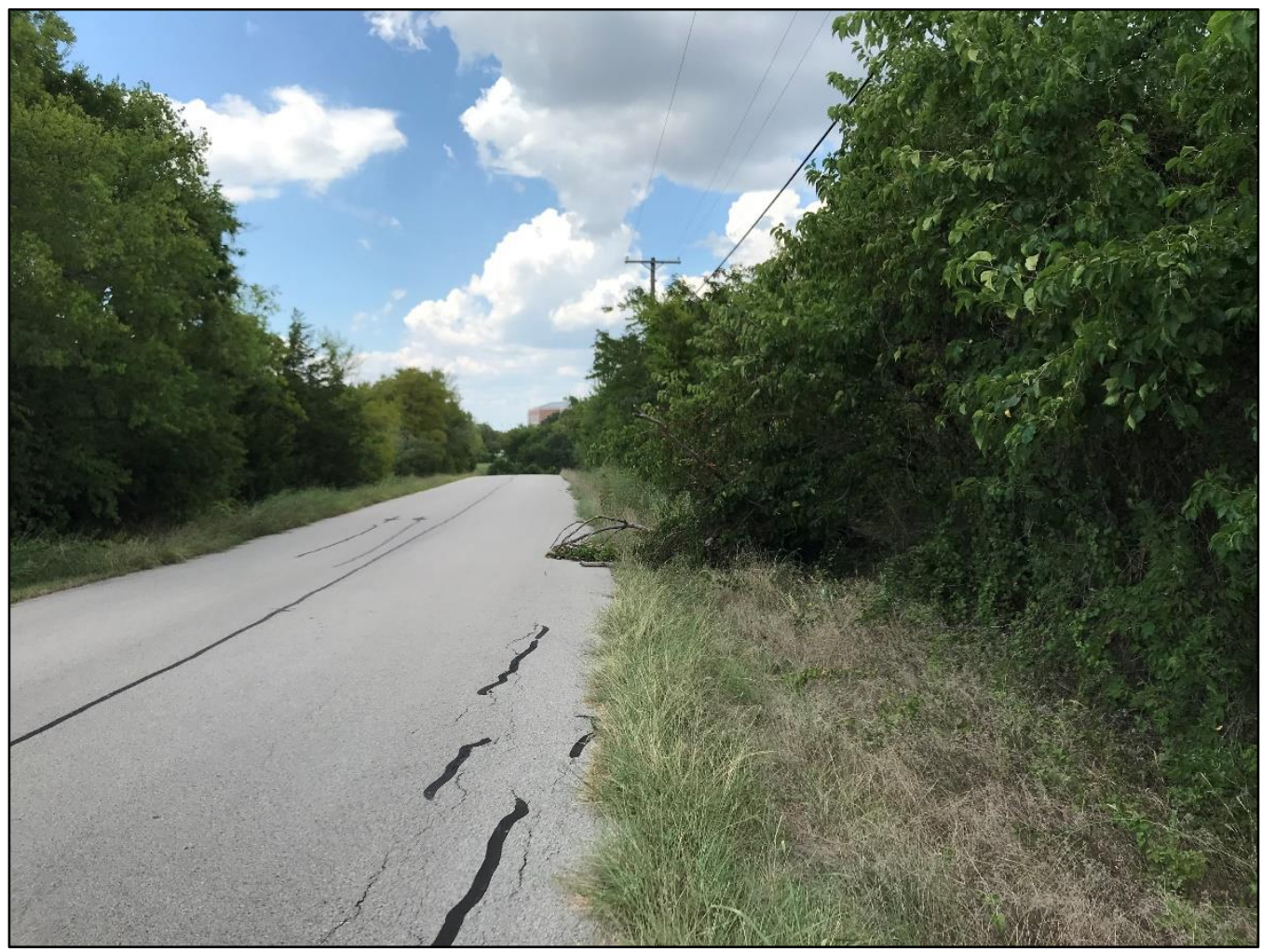

Figure 6. Transmission line easement east side of James Pitts Drive. Facing north. 


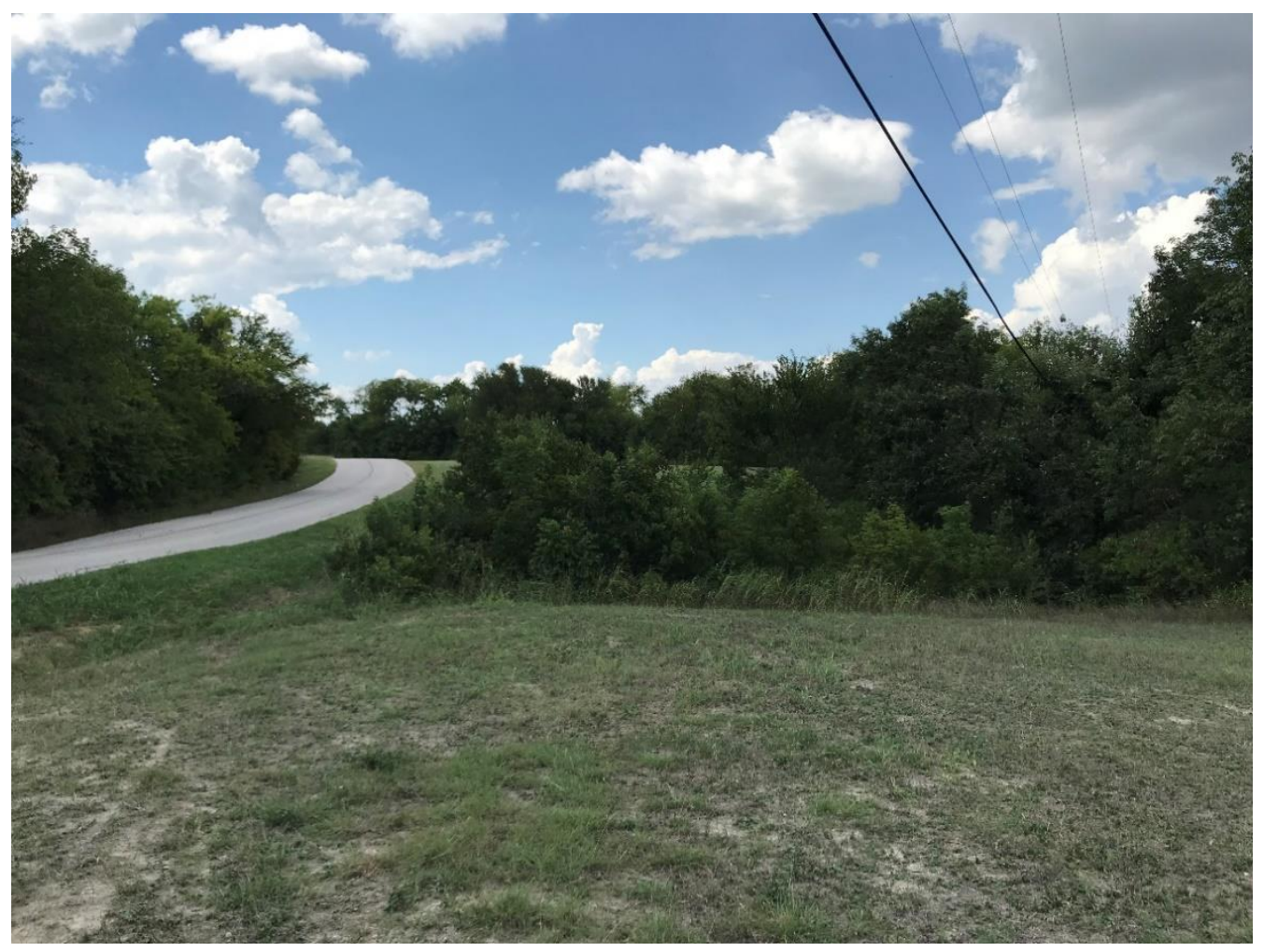

Figure 7. Transmission line easement east side of James Pitts Drive at angle to the northwest. Facing northwest.

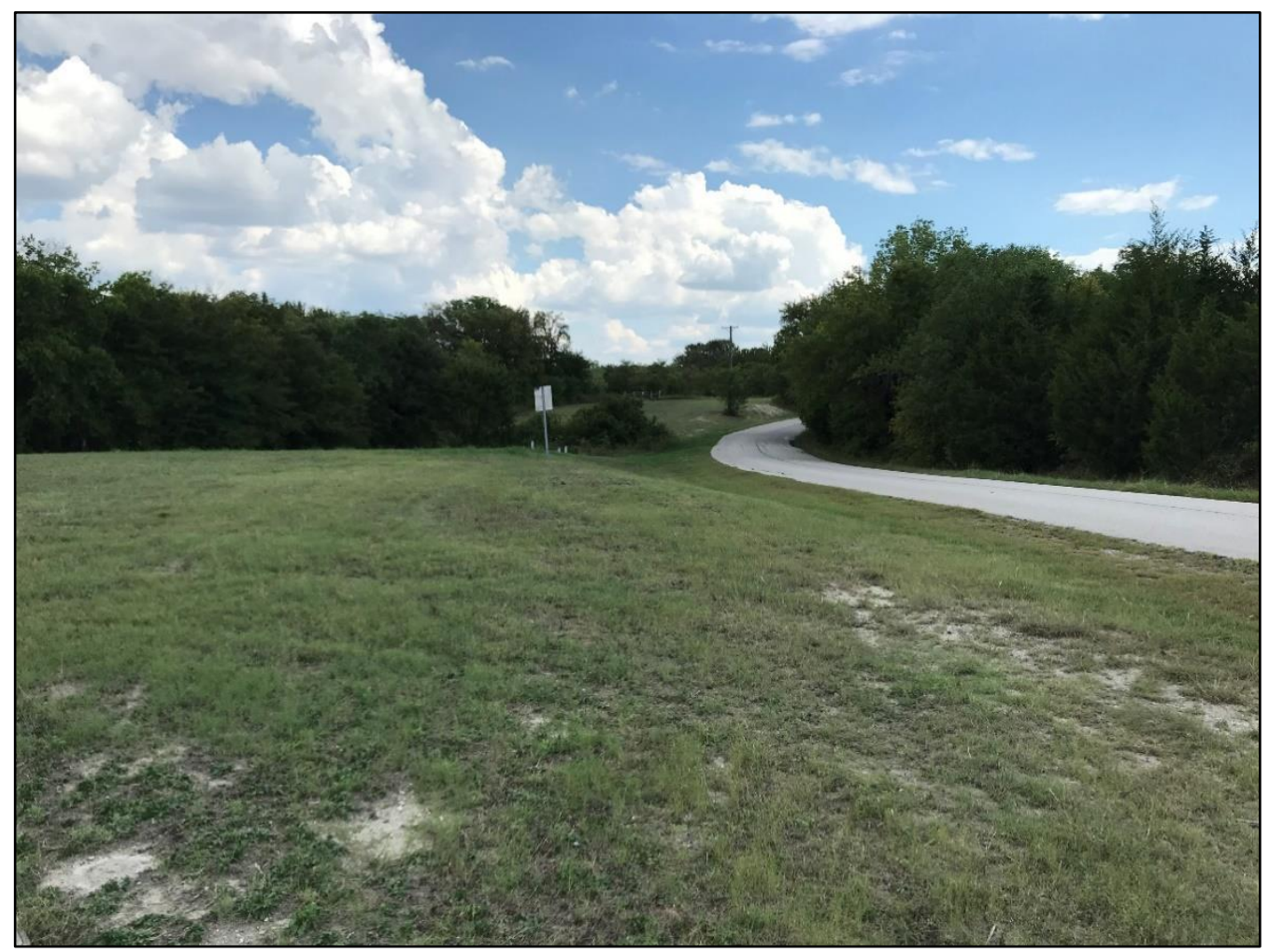

Figure 8. Transmission line easement north side of James Pitts Drive at angle to the northwest. Facing southeast. 


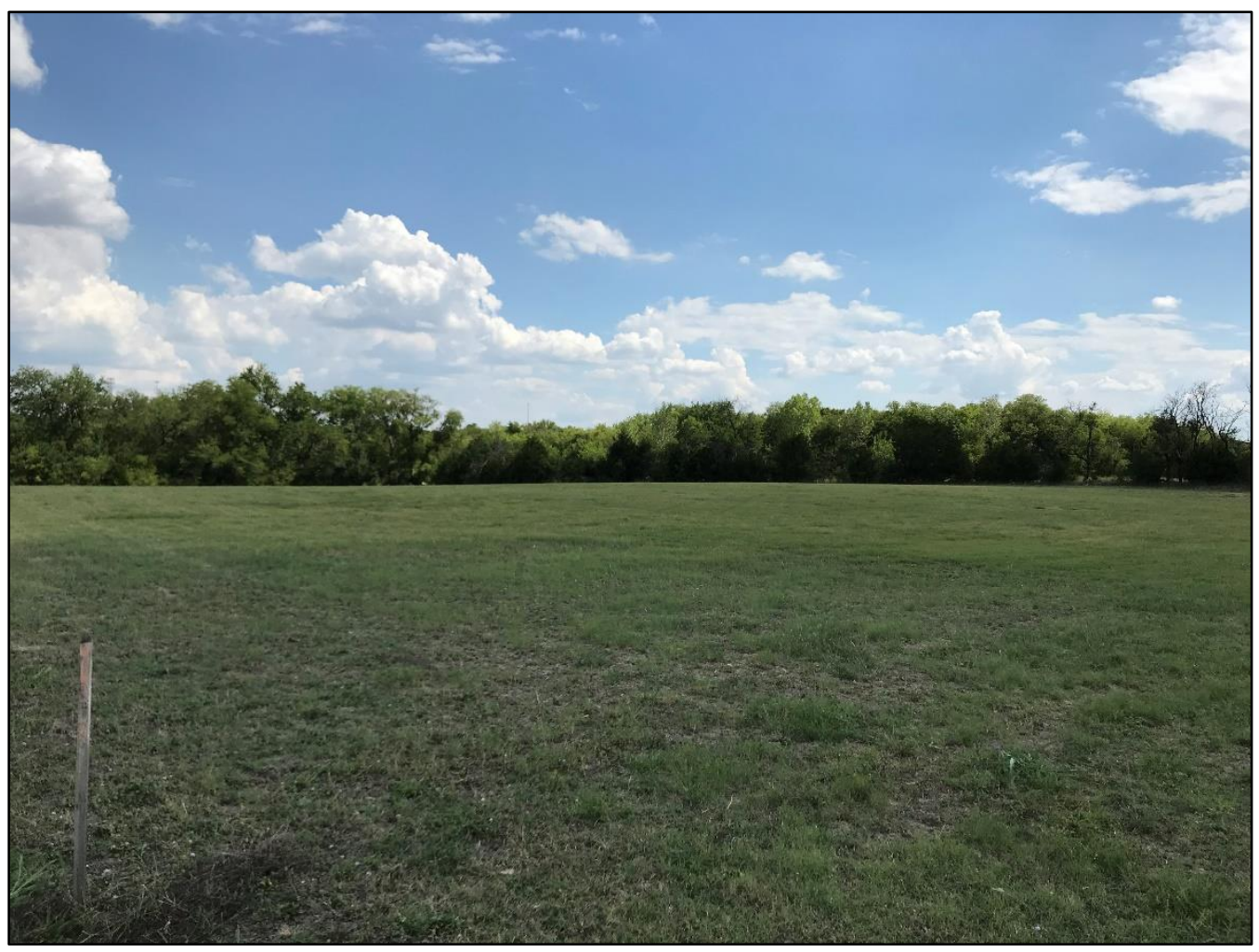

Figure 9. Transmission line easement east side of Community Avenue. Facing southeast.

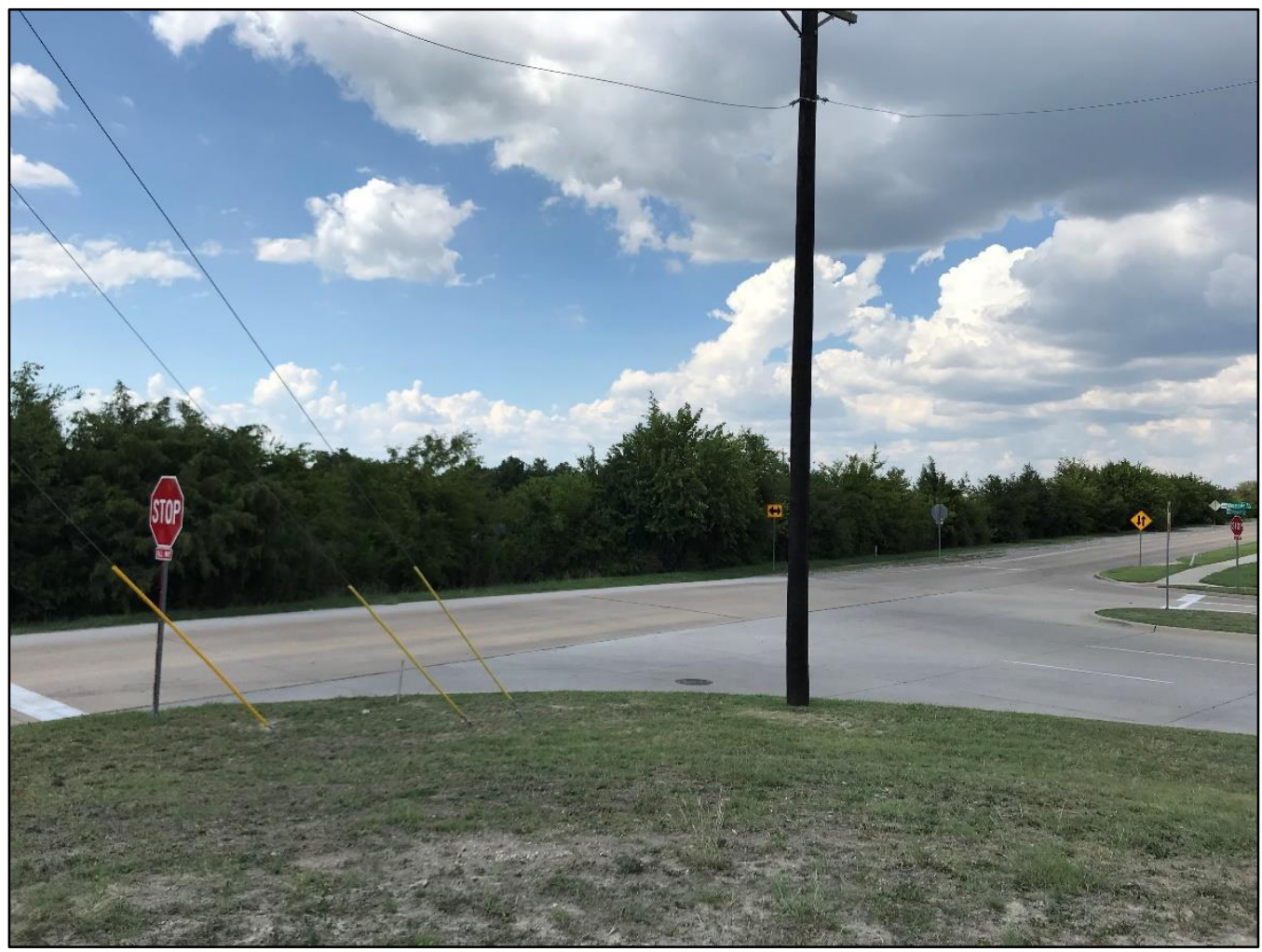

Figure 10. Transmission line easement crossing at intersection of Community Avenue and Bloomdale Road (foreground). Facing northwest. 


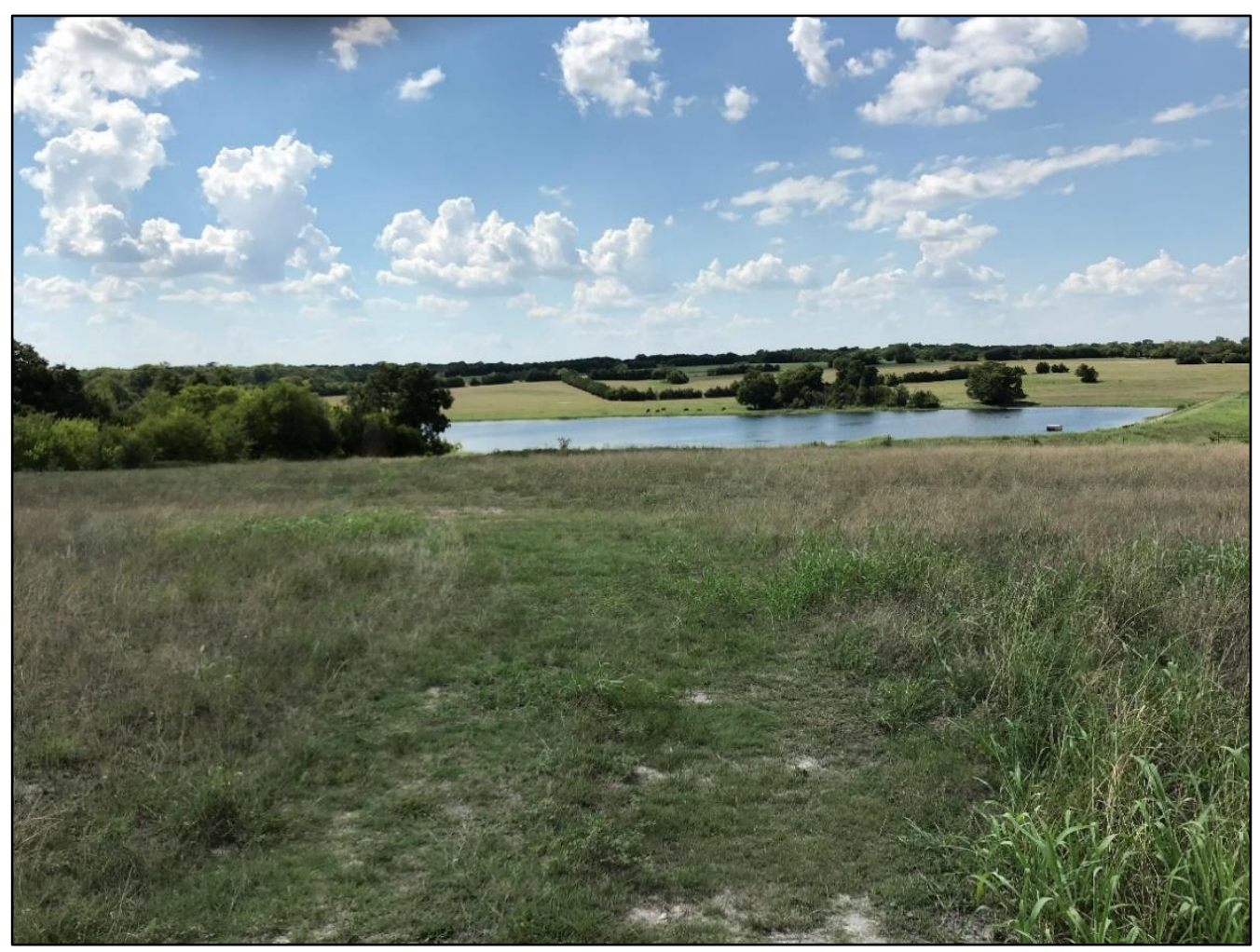

Figure 11. Transmission line easement east side of NRCS earthen dam (right) and SWCD Site 17 reservoir. Facing northwest.

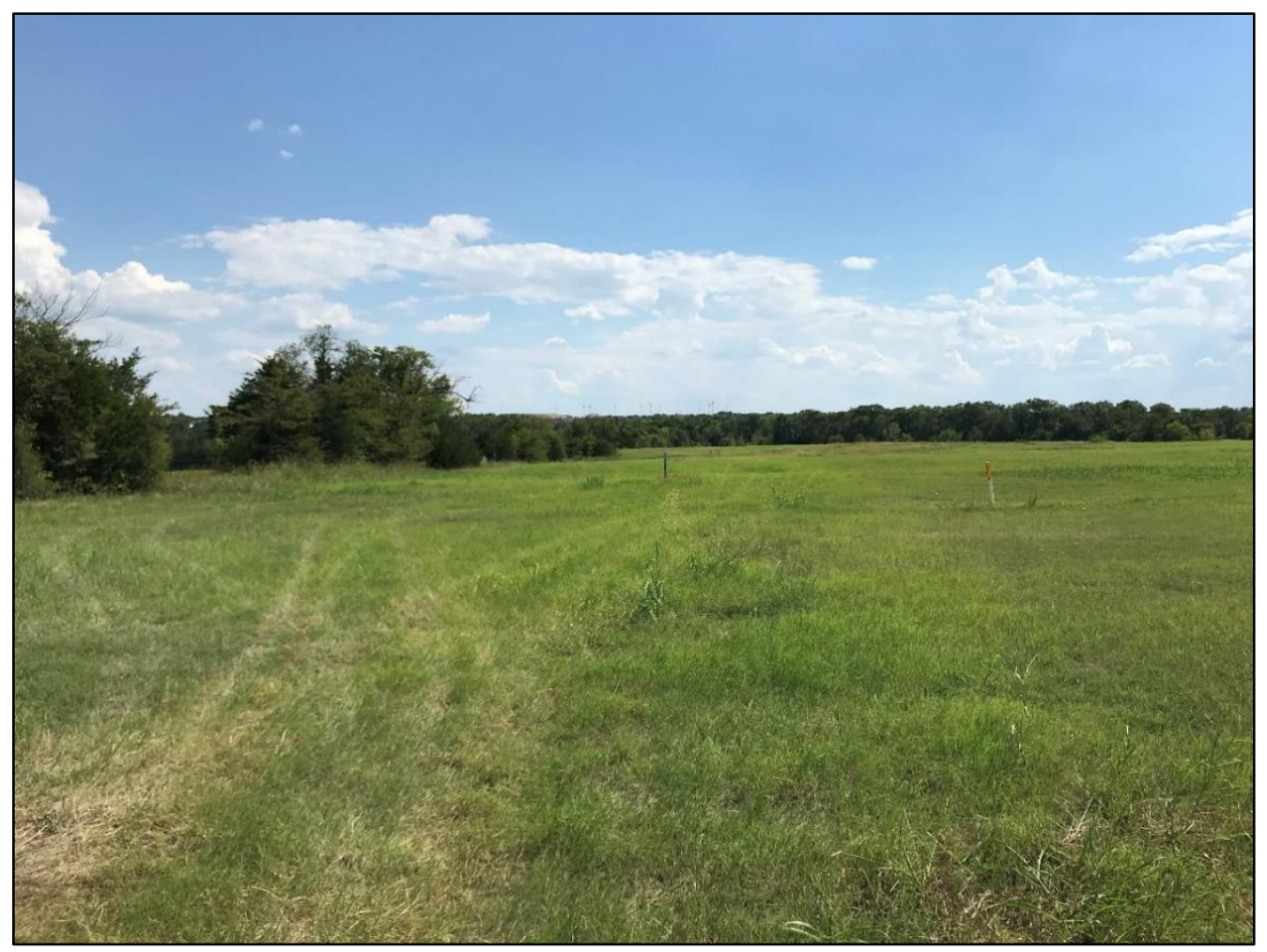

Figure12. Transmission line easement termination point west of SWCD Site 17 reservoir. Facing southeast. 


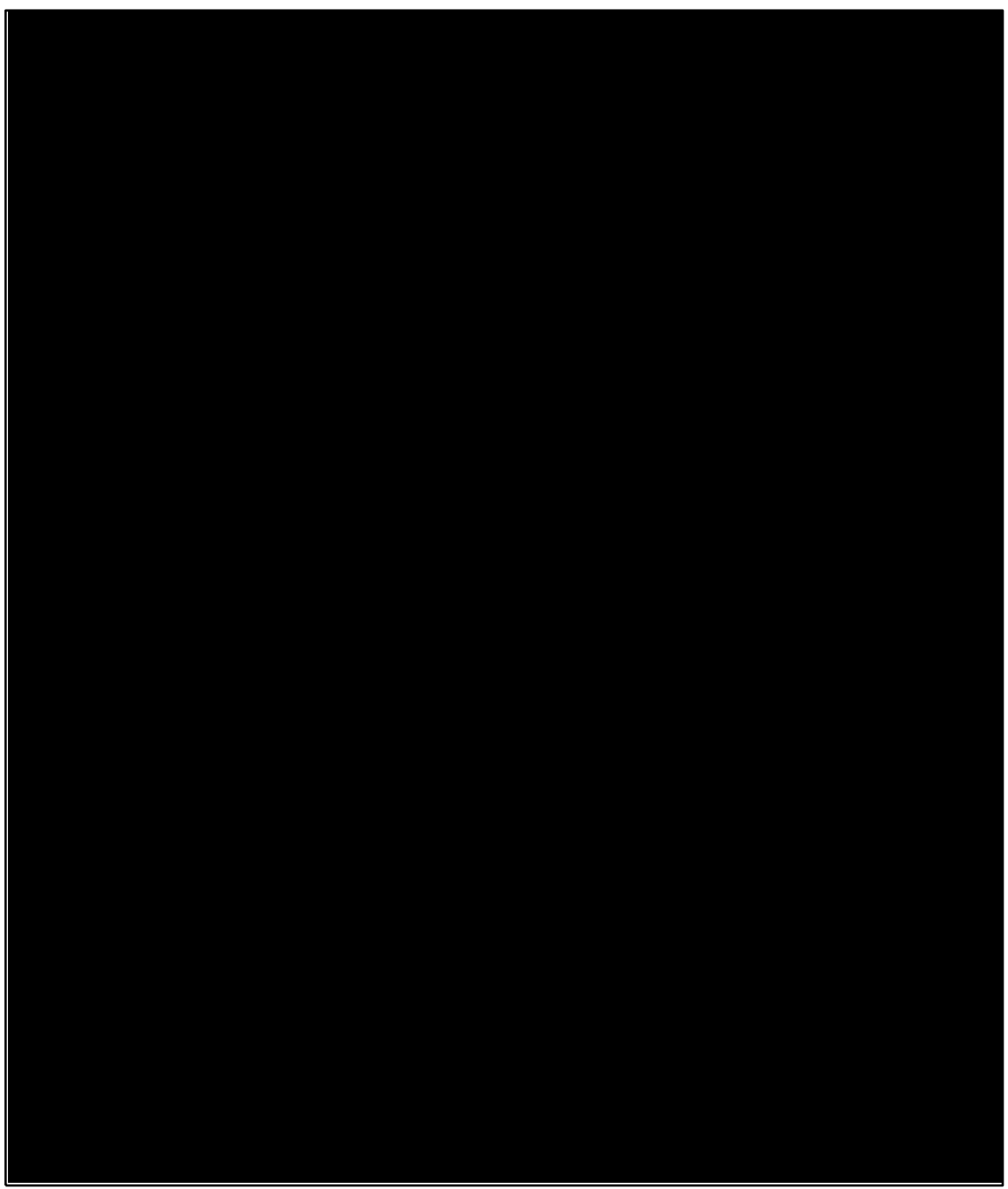

Figure 13. Site 41COL324, overview. Facing north. 


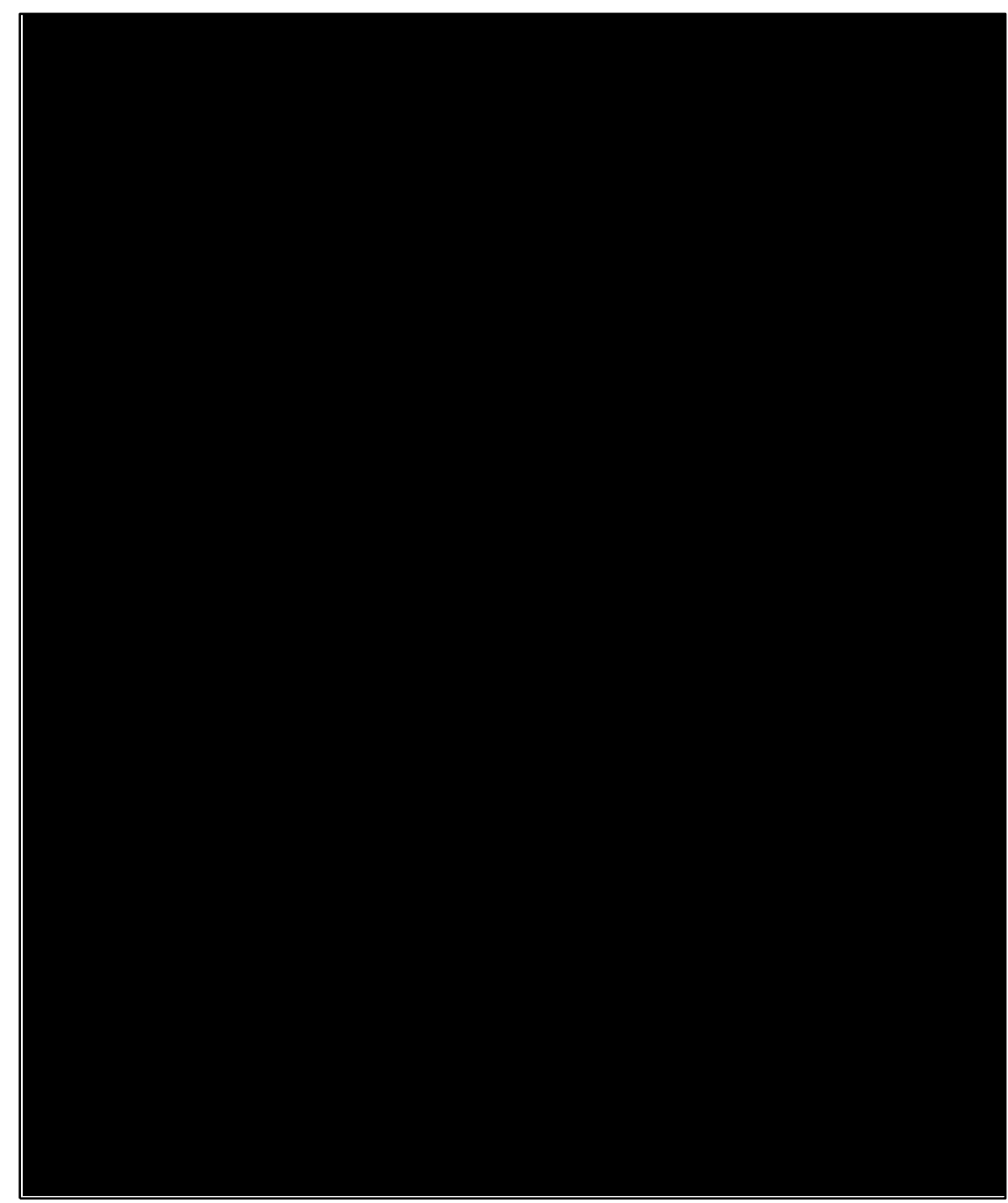

Figure 14. Site 41COL324, overview. Facing south. 


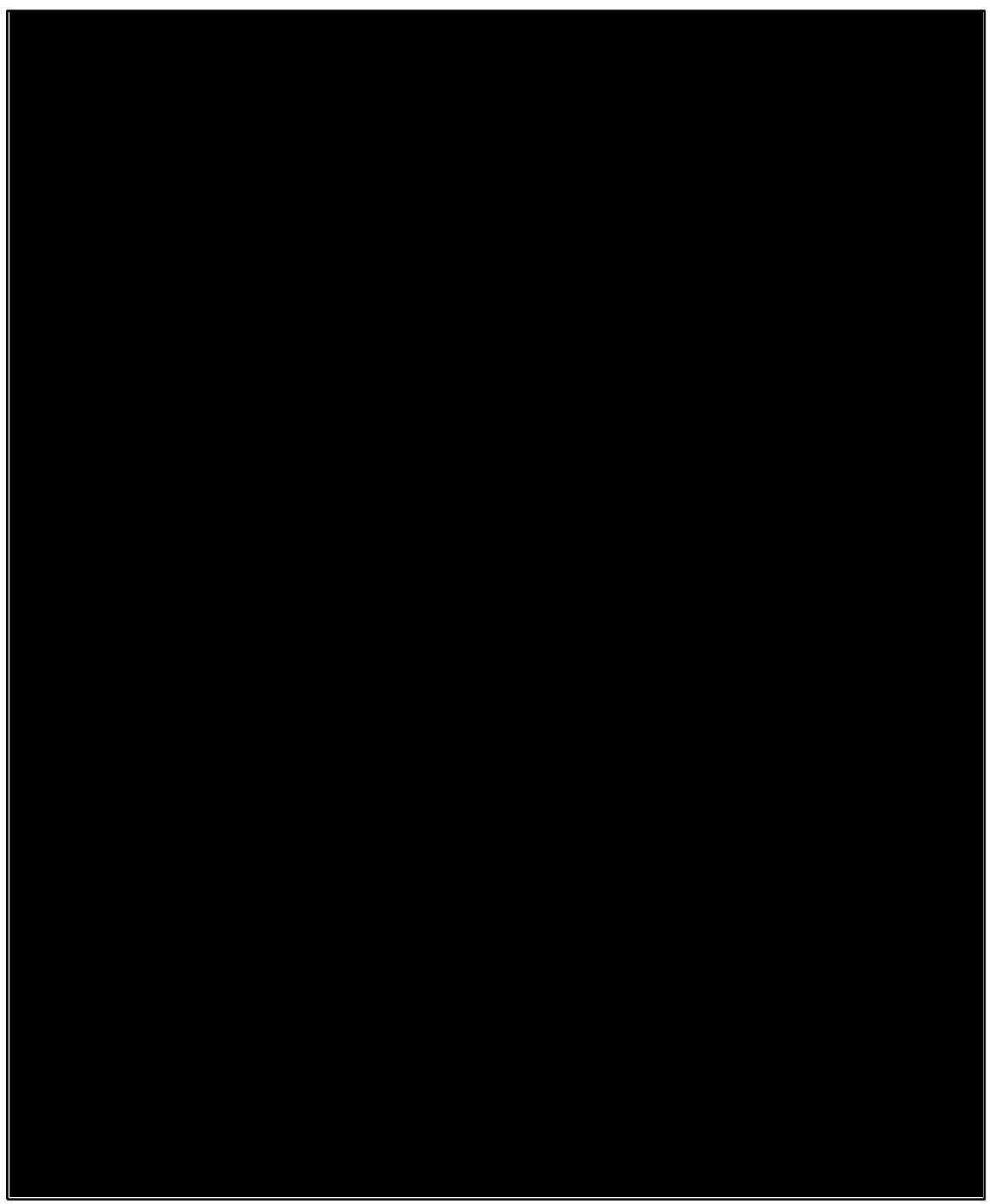

Figure 15. Site 41COL324, overview. Facing east. 


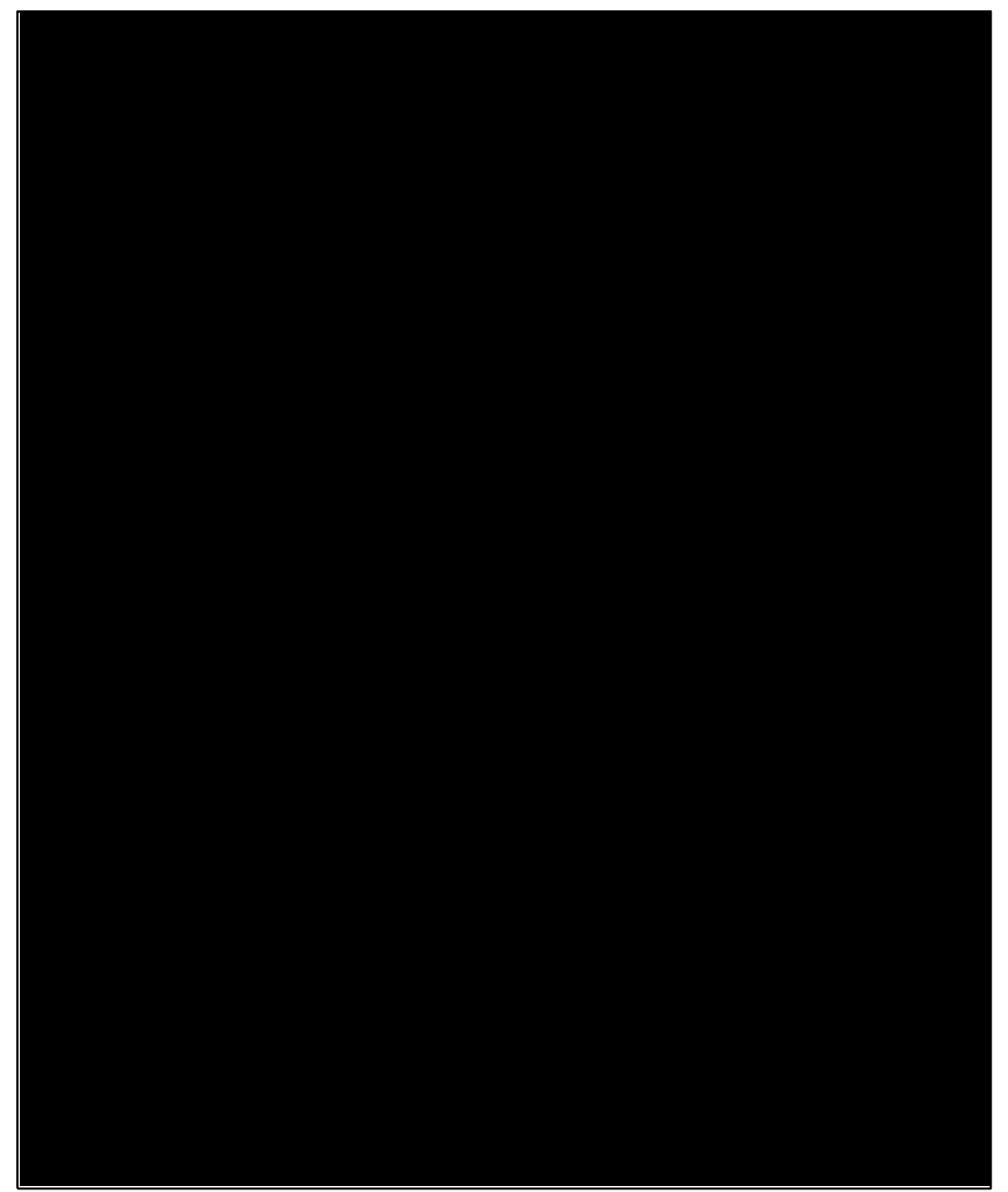

Figure 16. Site 41COL324, overview. Facing west. 


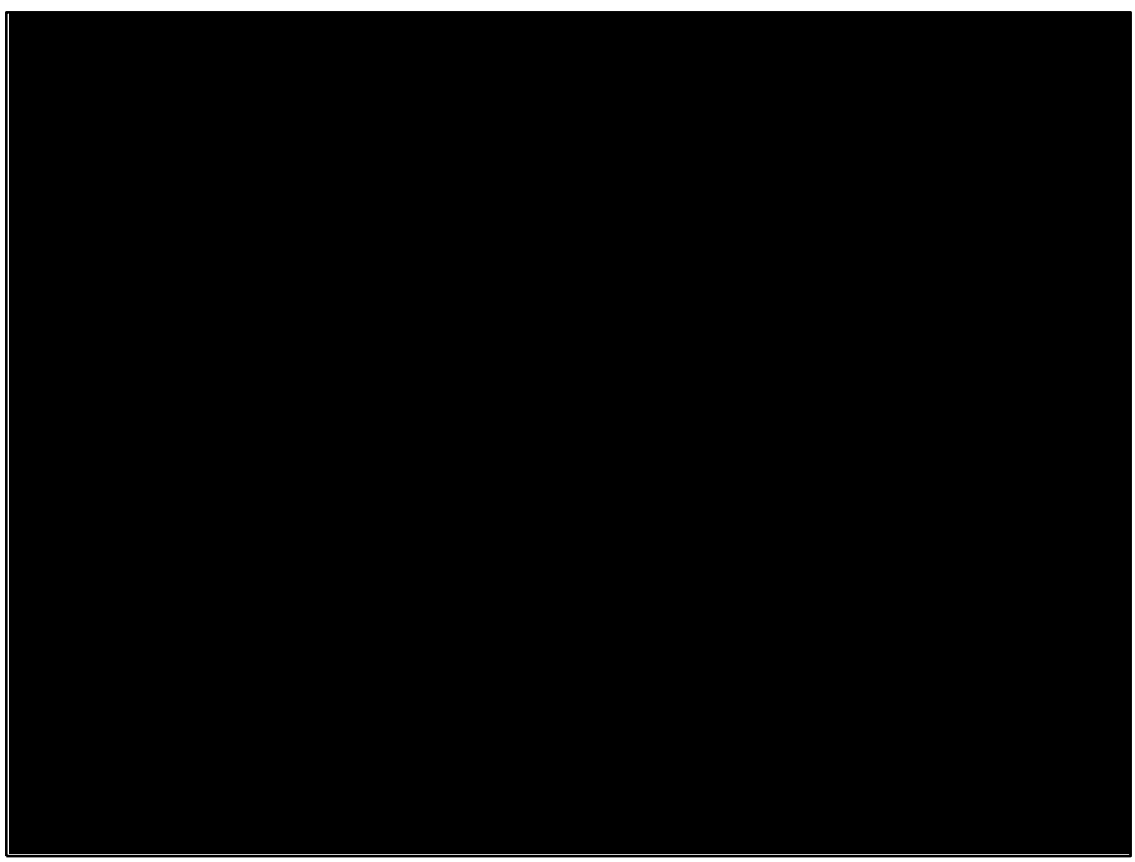

Figure 17. Site 41COL324 well feature with PVC piping and fittings.

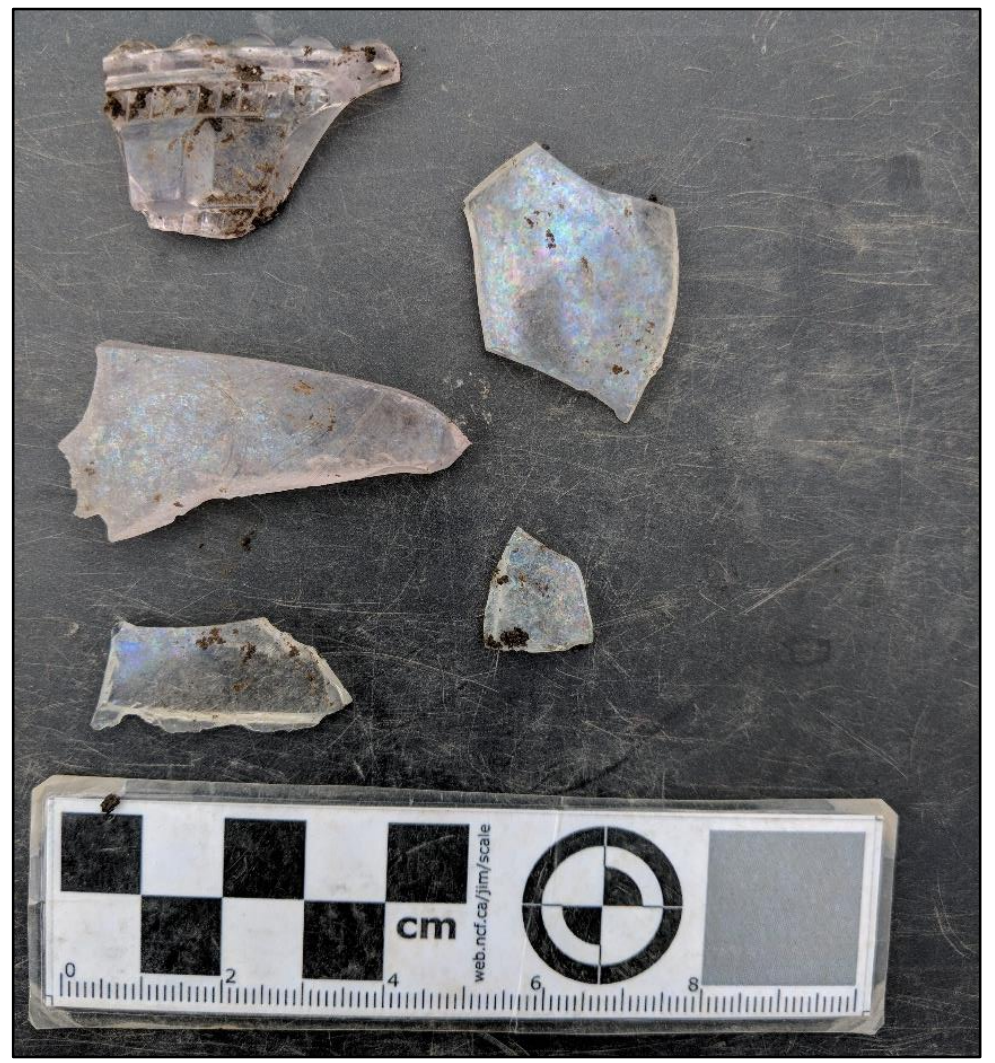

Figure 18. Historic artifacts from site 41COL324. 


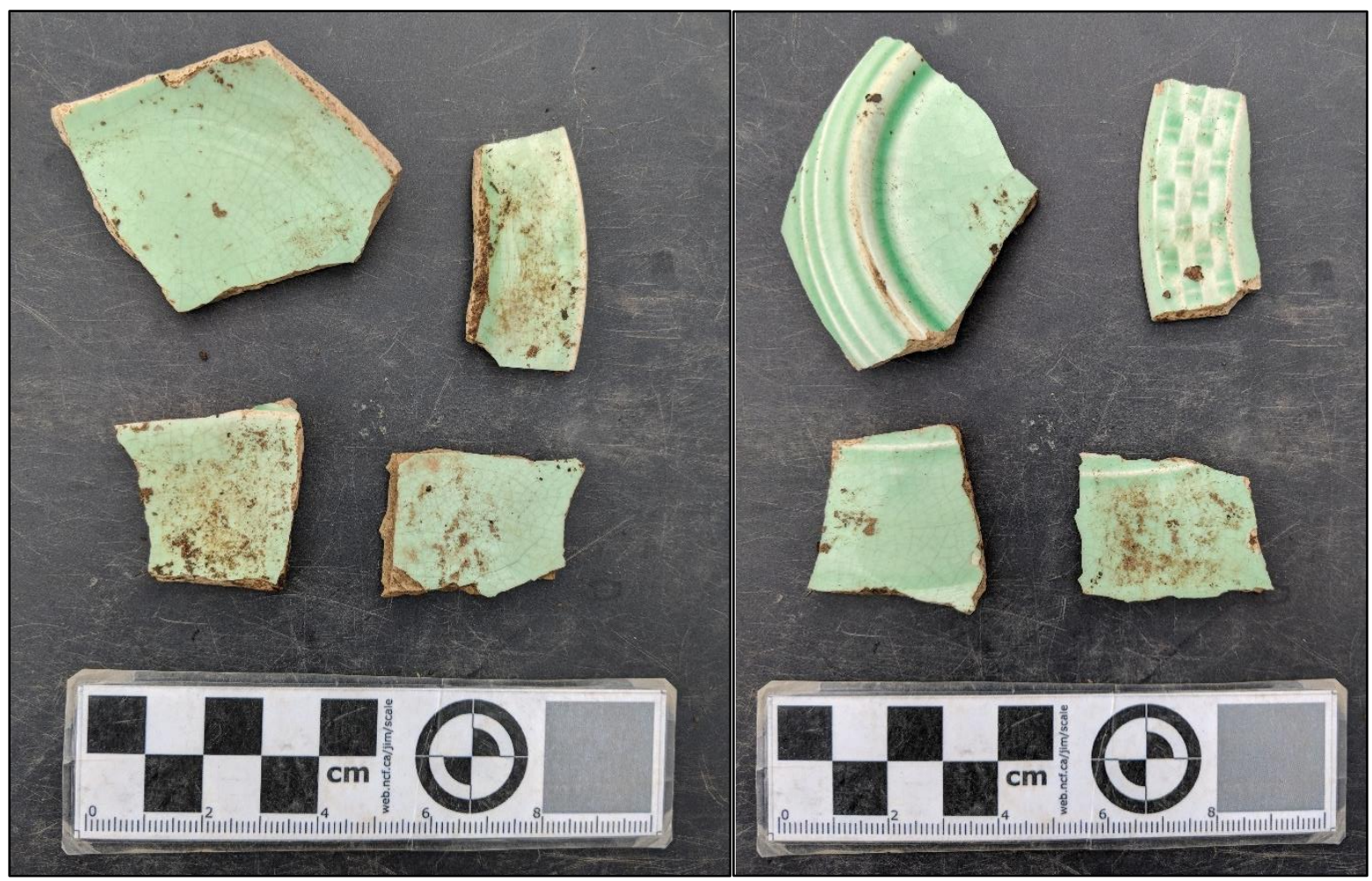

Figure 19 and 20. Site 41COL324 ceramic whiteware with monochrome, pale blue-green glaze.

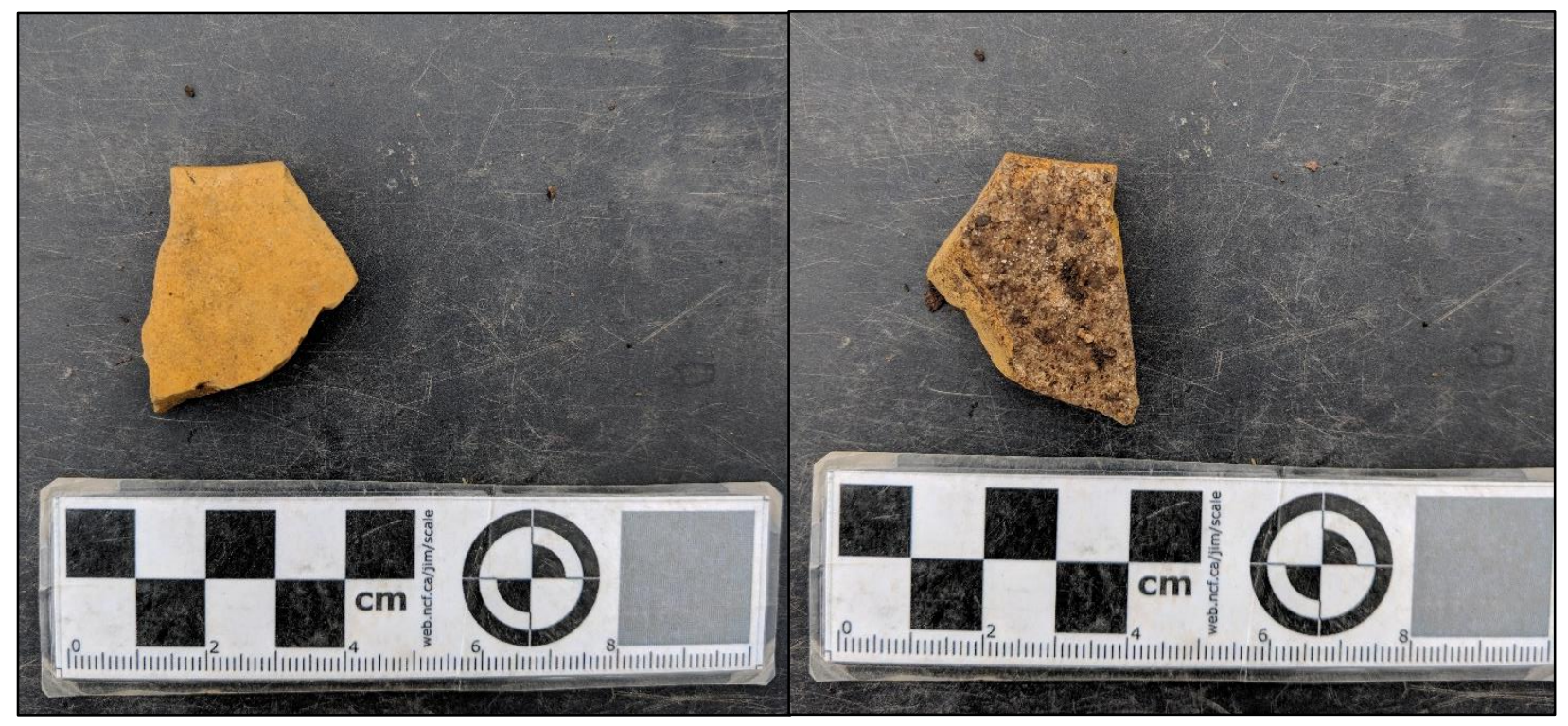

Figure 21 and 22. Site 41COL324 ceramic, amber colored, possibly a heater grate/panel rim fragment from a gas fireplace burner (heater). 


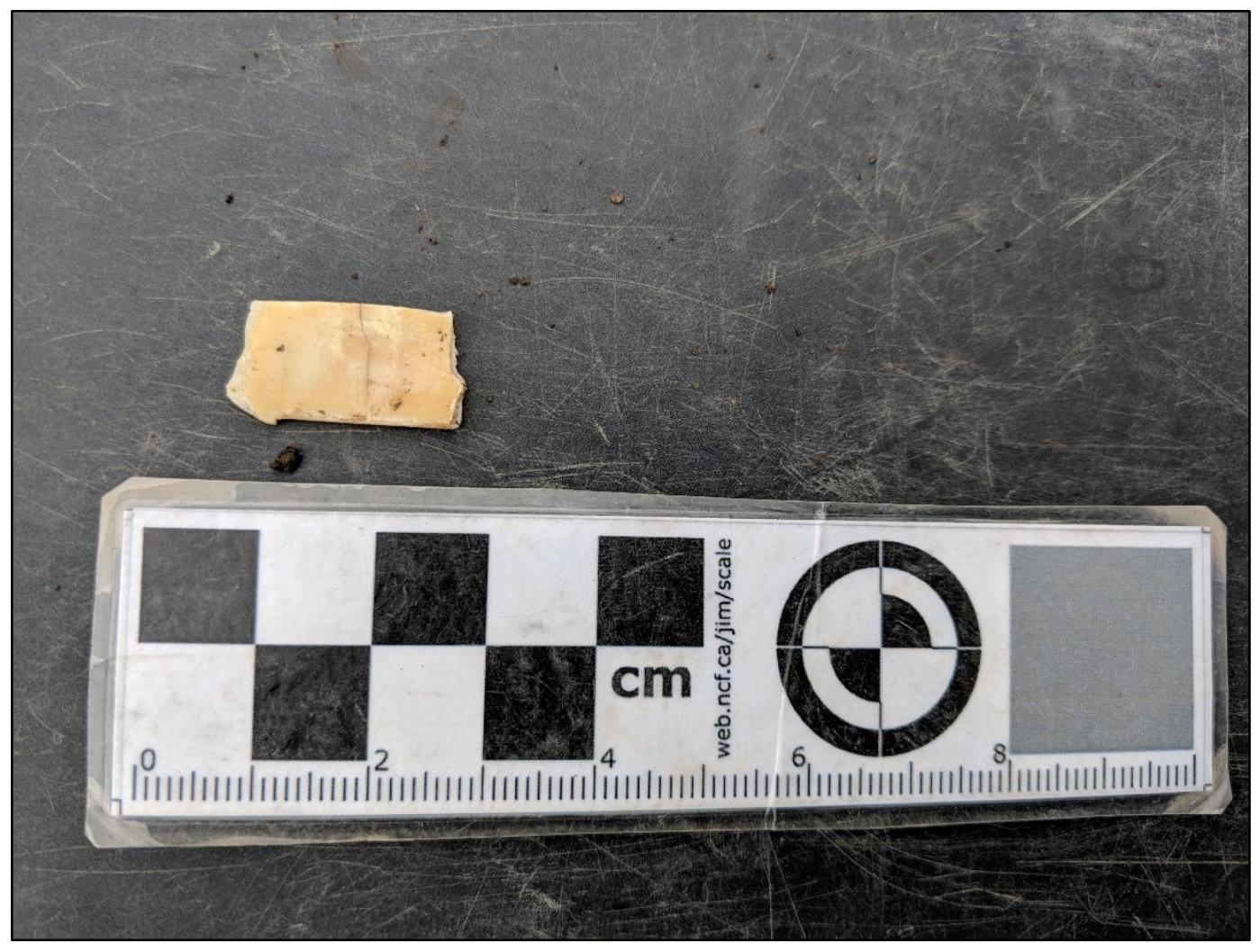

Figure 23. Site 41COL324 resin fragment. Possibly Bakelite. Pearled surface, pale yellow in color. 